\title{
Türkiye'de Kentsel Tarımın Yapısal ve Oluşumsal Çerçevesi
}

\author{
Serap Kayasü ${ }^{1}$ \\ ORCID: 0000-0001-8477-0632
}

\author{
Büşra Durmaz ${ }^{2}$ \\ ORCID: 0000-0003-2792-9592
}

\section{Öz}

Kentsel tarım kavramı, tükenen kaynaklar, temiz, ucuz ve güvenli gıdaya erişim, açık ve yeşil alan yaratma potansiyeli, sosyal sermayeye olan katkısı sebebi ile Türkiye'de ve dünyada tartışılmakta, örnekleri oluşturulmaktadır. Bulunduğu alanlarda ekonomik, çevresel ve toplumsal katkı sağlayan kentsel tarımın önemi, günümüzde yaşanan COVID-19 salgın koşulları ile daha da artmıştır. Yeşil-mavi alt yapı ve doğa tabanlı çözüm uygulamalarında da kentsel tarım konusu çözüm olarak önemsenmektedir. Bă̆lamı çok geniş olmakla beraber bu çalışmada, kentsel tarımın Türkiye'deki yapısal ve oluşumsal süreçleri değerlendirmeye alınacaktır. Araştırma yöntemi olarak yapısal çerçeve değerlendirilirken, Türkiyede'ki mevcut mevzuat, plan ve politika belgeleri kentsel tarım bağlamında tartışılarak bu konudaki kısıtlar ve olanaklar özetlenmiştir. Oluşumsal çerçevenin yöntemini ise, STK'lar, vatandaş inisiyatifleri ve toplumsal örgütlenmeler aracılığı ile oluşturulan mahalle ölçeğindeki Türkiye ve dünyada gerçekleştirilen kentsel tarım örnekleri oluşturmuştur. Araştırmanın sonucunda gelinen nokta ise; Türkiye'de kentsel tarımın anlaşılabilir bir çerçevesini ortaya koymak için yapısal ve oluşumsal edinimlerin birlikte açıklanmasına ve değerlendirilmesine ihtiyaç olduğudur.

Anahtar Kelimeler: Kentsel tarım, Türkiye bağlamı, yapısal çerçeve, oluşumsal çerçeve.

\footnotetext{
${ }^{1}$ Prof. Dr, Orta Doğu Teknik Üniversitesi, E-mail: kayasu@metu.edu.tr

2 Doktora Öğrencisi, Orta Doğu Teknik Üniversitesi, E-mail: durmaz.busra88@gmail.com

idealkent @ Kent Araştırmaları Dergisi (Journal of Urban Studies) 


\title{
Structural and Formative Framework of Urban Agriculture in Turkey
}

\author{
Serap Kayas ̈̈ ${ }^{3}$ \\ ORCID: 0000-0001-8477-0632
}

\author{
Büşra Durmaz ${ }^{4}$ \\ ORCID: 0000-0003-2792-9592
}

\begin{abstract}
Urban agriculture is discussed and its examples are implemented in Turkey and in the world due to its depleted resources, access to clean, cheap and safe food, its potential to create open and green spaces, and its contribution to social capital. The importance of urban agriculture, which contributes to economic, environmental and social well-being, has increased even more due to the current COVID-19 pandemic conditions. Urban agriculture is considered as a solution in green-blue infrastructure and nature-based solution applications. Despite the broad context, in this research, the structural and formative processes of urban agriculture in Turkey were evaluated. While discussing the structural context, as the research method, the current legislative structure, plans and policy documents in Turkey were discussed in the context of urban agriculture and the constraints and possibilities in this regard were summarized. The method of the formative context was mentioning the examples of urban agriculture in Turkey and in the world at the neighborhood scale that had been created by NGOs, citizen initiatives and social organizations. The ultimate point reached in the research is that the integration of structural and formative acquisitions is needed to draw the framework of urban agriculture in Turkey.
\end{abstract}

Keywords: Urban agriculture, Turkish context, structural framework, formative framework.

\footnotetext{
${ }^{3}$ Prof. Dr, Middle East Technical University, E-mail: kayasu@metu.edu.tr

${ }^{4}$ Ph.D. Candidate, Middle East Technical University, E-mail: durmaz.busra88@gmail.com 


\section{Giriş}

Günümüzde, küresel ve doğal kaynakların \%75'inin şehirlerde tüketildiği bilinen bir gerçektir. Verimli topraklar, gida, temiz su ve temiz hava giderek azalmakta ve dünya bir kutlk durumuna doğru hızla ilerlemektedir. Kentlerin, kaynak tüketimine ve yaşanacak kıtlığa uyum sağlama kapasitelerini artırmak ve çözüm üretebilmek için yeşil-mavi altyapı (green-blue infrastructure) ve doğa tabanlı çözümler (Nature-based Solutions) geliştirmektedir. Küçük ölçekli imalat, kentsel yapılı çevrede döngüsellik ve döngüsel ekonomi ile kentsel tarım konuları bu çözümlere yönelik uygulamalardan birkaçıdır. Bu çalışmanın vurgusu 'kentsel tarım' üzerine olacaktır. Fakat öncesinde bu bağlamda değerlendirilen döngüsel ekonomi kavrami tartşslacaktır.

Hammadde kaynaklarının azalması ile birlikte döngüsel ekonomi kavramı giderek önemli hale gelmektedir. Döngüsel ekonomi; kaynakların tekrar dönüştürüldügü ya da tekrar kullanıldığı ve artık maddenin de tekrar üretimde kullanılmaya döndüğü bir sistemdir. Günümüzde, belirtilen bu kaynak tüketiminin en belirgin nedeni olarak görülebilecek endüstriyel üretimin döngüsel hale gelmesi için her düzeyden bir yeniden yapılandırma gerekmektedir. Kaynakların alınıp kullanulmasından, tasarım ve üretim süreçlerine, lojistik ve dağıtıma kadar her adım, döngüsellik ve sürdürülebilirlik çerçevesinde şekillendirilmelidir. Kentsel alanların da ekonominin döngüselliğine adapte olmasının kaçınılmazlığı ile birlikte üreticiler, tedarikçiler ve tüketicilerin de bu bağlamda davranış değişikliğine gitmektedir.

Bütün bu gelişmelerin yanında, günümüzde yaşanan COVID-19 küresel salgını ile birlikte, doğanın ve sağlıklı yaşamın önemi bir kat daha artmıştır. Salgın sebebi ile çöküş yaşayan toplumun tekrar canlanabilmesi için başta sağlık, ilaç ve gıda takviyelerinin yanında, eğitim, tarım ve tarıma dayalı üretime dayalı sektörlerde verimliliği ve sürdürülebilirliği sağlamak da hayati önemdedir. Bu bağlamda, güvenli gıda üretimi ve güvenli gıdaya erişimin bir arac olarak da 'kentsel tarım' konusu, dünyada ve Türkiye'de kent gündemindeki yerini almıştır.

Yeni gelişen koşullar ile dünyada öne çkan kentsel tarımın Türkiye uygulamaları için net olarak geliştirilmiş tanım, yöntem, kısıtlamalar ve olanaklanı içeren bir çerçeve bulunmamaktadır. Kentsel tarımın kavramsal olarak nasıl konumlandırlacağı, uygulamada ne tür bir yasal dayanak ile ya da nasıl bir dışsal kuralı ya da örneği dikkate alarak yeni uygulamalar yapılabileceğini netleştirmek gerekmektedir. Kentsel tarım konusu oldukça geniştir ve farklı bağlamlarda tartş̧labilmektedir. Bu çalışmanın bağlamın: “Türkiye'de Kentsel Tarımın Yapısal ve Oluşumsal 
Çerçevesi" oluşturmaktadır. Bu kapsamda, yapısal çerçevenin içeriğini; Türkiye'de kentsel tarım konusundaki mevzuat, planlar, strateji ve politika belgeleri oluşturmaktadır. Strateji ve politika belgeleri incelemesinde ulusal, kentsel ve ilçe ölçeğinde incelemeler yapılmış olup Ankara ili ve Çankaya ilçesi örnek olarak ele alınmıştır $^{5}$. Oluşumsal çerçevenin içeriğini ise; Sivil Toplu Kuruluşları (STK'lar), örgütsel yapılanmalar ve vatandaş inisiyatifleri aracilığı ile oluşturulan kentsel tarım alanları ve uygulamaları oluşturmaktadır.

Yalnızca mevzuat araştırmasının edinimleri ile ya da mevcut oluşumsal örnekleri göz önüne alarak yeni kentsel tarım uygulamalarını gerçekleştirmek kavram için bir çerçeve ortaya koymadığı için anlamsız olacaktır. Bu kapsamda araştırmanın hipotezi; “Türkiye'de kentsel tarımın çerçevesini oluşturmak için, yapısal ve oluşumsal edinimlerin birlikteliğine ihtiyaç vardır" olarak kurgulanmıştır. Araştırma yöntemi ise; yapısal dinamikleri değerlendirebilmek için Türkiye'deki mevcut mevzuat, plan, politika belgelerini yerel ölçekte Ankara-Çankaya örnek olarak alınarak kentsel tarım bağlamında analiz etmek, oluşumsal dinamikleri değerlendirebilmek için ise mahalle örgütlenmeleri aracllı̆ı ile oluşturulan kentsel tarım uygulamalarını örnekler üzerinden incelemek şeklinde belirlenmiştir. Bu bağlamda ilk olarak kentsel tarımın tanımı ve tarihsel gelişimi konusunda kısa bir değerlendirme yapılacak, ardından kentsel tarımın yapısal ve oluşumsal çerçevesi örnekler analizi ile birlikte ele alınacak ve son olarak yapısal ve oluşumsal çerçevelerin birlikteliğinin önemi vurgusu tartş̧ma ve sonuç bölümünün ana eksenini oluşturacaktir.

\section{Kentsel Tarım Kavramı}

Bu bölümde ilk olarak kentsel tarımın tanımı yapılacak ve hangi amaçlara hizmet ettiği konusu değerlendirilecektir. Bunu yaparken Birleşmiş Milletler Sürdürülebilir Kalkınma Amaçları'ndan ${ }^{6}$ kentsel tarım ile ilgili olanlara vurgu yapılacaktır. İkinci kısımda ise kentsel tarımın tarihine kısaca değinilecektir.

\section{Kentsel tarim nedir?}

Çoğunlukla kırsal bağlam ile ilişkilendirilen tarım kavramı, son yıllardaki kentsel niteliği ile yeni bir boyut kazanmaktadır. Hızlı kentleşme, kırsaldan kentlere göç, yüksek işsizlik ve kentsel yoksulluğun neden olduğu ekonomik,

\footnotetext{
${ }^{5}$ Ankara-Çankaya'nın inceleme analı olarak seçim gerekçeleri 'Yapısal Çerçeve' başlığı altında verilmiştir.

${ }^{6}$ Sürdürülebilir Kalkınma Amaçları (SKA), Birleşmiş Milletler üyesi ülkeler tarafindan 2030 sonuna kadar ulaşılması amaçlanan hedefleri içermektedir. Tüm dünyada açlık ve yoksulluğa son vermek, iklim değişikliği ile mücadele etmek, toplumsal cinsiyet eşitliğini sağlamak, nitelikli eğitimi, sorumlu üretim ve tüketimi yaygınlaştırmak gibi 17 ana başlıktan oluşmaktadır. Ocak 2016'da yürürlüğe girmiştir.
} 
çevresel ve toplumsal sorunlar kentsel bağlamda tarımsal faaliyetlerin artmasına neden olmuştur. Bu yeni akım "Kentsel Tarım" olarak adlandırılmaktadır. Kentsel tarım faaliyetleri; ekonomik, çevresel ve toplumsal alanlarda olumlu etkileri olması nedeniyle dünya genelinde hızla gelişmektedir. Bu nedenle birçok ülkede sürdürülebilir kalkınma stratejisi olarak kullanılmaktadır. Birleşmiş Milletler tarafından açıklanan, Kentsel Tarım ile ilişkili Sürdürülebilir Kalkınma Amaçları (BM, 2021):

Amaç-01 Yoksulluğun tüm biçimlerini her yerde sona erdirmek,

Amaç-02 Açlığı sona erdirmek, gida güvenliğini sağlamak ve iyi beslenmeye ulaşmak ve sürdürülebilir tarımı teşvik etmek,

Amaç-12 Sürdürülebilir tüketim ve üretim kalıplarını sağlamak,

Amaç-15 Karasal ekosistemlerin sürdürülebilir kullanımını korumak, eski haline getirmek ve teşvik etmek, ormanları sürdürülebilir bir şekilde yönetmek, çölleşme ile mücadele etmek ve arazi bozunumunu durdurmak ve tersine çevirmek ve biyolojik çeşitlilik kaybını engellemek şeklinde sıralanabilir.

Birleşmiş Milletler Gıda ve Tarım Örgütü'ne göre (FAO) kentsel tarımın tanımı, ev bahçeleri, balkonlar, çatılar ve arka bahçeler, kamusal ve kurumsal alanlardaki bahçeler, boş araziler vb. gibi farklı kentsel bağlamlarda, dikey tarım, topraksız tarım veya seracılık gibi farklı yöntemler kullanılarak yerel halk için gıda üretmektir. Bunun yanında FAO'ya göre özellikle gelişmekte olan ülkelerde artan kentli nüfusla beraber işsizlik, gıda güvencesi ve sağlıksız beslenme gibi sorunlar da artmaktadır. Kentsel tarım; işsizlik, gıda güvencesi, yetersiz beslenme gibi sorunların çözümünde önemli bir rol oynamaktadır (FAO, 2011).

Philips (2013)'e göre kentsel tarım, içerisinde farklı etkinliklerin gerçekleştirilebildiği ve farklı amaçlara hizmet edebilecek alan olarak tanımlanmaktadır. Eğlence ve serbest zaman etkinlikleri, ekonomik canlılığı getirecek ticari girişimler, bireysel esenliğin ve toplumsal sağlığın ve refahın elde edildiği mekân kullanımı, peyzaj çalışmaları, çevresel restorasyon ve iyileştirme bunlardan bazılarıdır.

Tüm bu tanımlar birleştirildiğinde kentsel tarım ile gıdanın üretildiği ve işlendiği, kentlerin doğal kaynaklarına katkıda bulunulduğu, vatandaşlar için gıda güvenliği, eğlence ve eğitim sağladığı gibi faydalar çıkarılmaktadır. Bu faydaların yanında, kentlerde ekonomik, çevresel ve toplumsal sorunların çözümüne de katkı sağlamaktadır. 
Son yıllarda iklim değişikliği ve kentsel alanlarda gıda güvenliğinin sürdürülebilirliği konusundaki endişeler sebebi ile kentsel tarımın önemi artmıştor (United Nations, 2015). Bunun yanında 2020 yllının mart ayından itibaren tüm dünyayı etkileyen COVID-19 salgını da kentsel tarımın önemini bir kez daha ortaya çıkarmıştır. Salgın koşullarında toplumlar bazı temel konuların öneminin daha fazla farkına varmaya başlamışlardır. Bu konular; sağlıklı g1daya erişimin önemi, gıda tedarik zincirindeki olası aksamalara karşı ne kadar dirençli olunduğunun sorgulanması ve devlet yönetimlerinin aldığı kararlarla salgın ile gelen önlemler kapsamında kentsel hareketlilikte kısıtlamalar ile birlikte insanların kentsel alanlarda gıda üretimi ile ilgilenmeye yönelmesidir. İnsanların kendi gıda tüketim ürünlerinden bir kısmını yaşadığı yere en yakın kentsel alanda üretebilmesi aynı zamanda serbest zaman etkinliği olarak kişisel psikolojik yeniden kalkınmaya da katkı sağlamaktadır.

\section{Kentsel Tarımın Tarihi}

İnsan var olduğu tarihten bu yana hep gıdanın peşinde koşmuştur. Avc1toplayıcı dönemden sonra tarım dönemine geçilmiştir. Çünkü tarımsal üretim yapmak, gida bulmanın hem daha kolay hem de güvenli bir yoludur. Tarımla beraber insanlar yerleşik düzene ve hayata geçiş yapmışlardır. Yerleşik düzene geçilince de nüfus artmaya başlamış ve tarımda bir artı değer yaratılmıştır. Bu da ticareti, mülkiyeti ve kentleri doğurmuştur (Taluğ, 2020).

1880'den 1900'lerin başlarına kadar, tahsisli bahçeler Londra, Paris ve Stockholm gibi Avrupa şehirleri için kentsel yoksulların kendi ihtiyaçlarını karşılamalarına yardımcı olmak için popüler bir yol haline gelmiştir. Bunun yanında kentsel ütopyalardan Ebenezer Howard'ın bahçe şehir hareketi, şehre yürüme mesafesindeki bahçeleri ve daha büyük tarım alanları tasarlanmasını içermekteydi. Bunun yanında 1930'larda Frank Lloyd Wright, geliştirdiği Broadacre City kavramı ile her konut mülkiyetinin bir dönümlük arazisinin tarımsal kullanıma ayrılmasını savunmuştur. 20. yüzyılda yaşanan Büyük Buhran, 1. ve 2. Dünya Savaşı ile birlikte kentsel tarımın önemi giderek artmıştır (AU Online, 2019).

Kentleşme 18 ve 19 yüzyıllarda sanayi devrimi ile birlikte hız kazanarak büyümüş ve birçok insan kentlere göç etmiştir. Hem zenginlik hem de yoksulluk bir arada yaşanmaya başlamıştır. Kent yoksullarının ortaya çıkması ve kent tarımının ilk örnekleri tam da bu zamana tekabül etmektedir. Paylaşım bahçeleri gibi uygulamalar o dönemdeki kent tarımına örnek olarak verilebilir. Daha sonra 1900'lü yıllarda tarım kentlere veda etmek üzereyken I. ve II. Dünya savaşları yaşanmış ve birçok çiftçi askere gitmek zorunda kalmıştır. 
İnsanlar gıdaya erişmek için kendi bahçelerinde üretim yapmaya başlamışlar ve böylece Zafer Bahçeleri (Victory Gardens) doğmuştur. 1950'li yıllara gelindiğinde, tarım kentten yavaş yavaş ayrılmaya başlamıştır. Bunun iki sebebi olduğu düşünülmektedir. İlki, kırsal alandaki tarımsal üretimin herkese yetecek kapasitede olması, ikincisi ise kent içinde yapılan tarımsal faaliyeler ile birlikte çiftlik hayvanlarının varlığının neden olduğu kirliliği bertaraf etmek için hijyen koşullarının kentte sağlanması gerektiği konusudur. Ancak bu durum, kentin doğa ve yiyeceği ile arasında büyük bir kopukluğa sebep olmuştur. Buna karşılık bir savunma mekanizması olarak çevre hareketleri doğmuştur. Kent tarımı bu çevre hareketinin uzantısı olarak tekrar gündeme gelmiştir. Özetle, kentleri doğuran da biçimlendiren de gıdadır, hep var olmuştur. 1950'lerle beraber kentin dışına çıkarılmaya çalışılsa da günümüz koşullarında, kent tarımının önemi bir kez daha gün yüzüne çkarılmıştır (Taluğ, 2020). Araştırmanın bundan sonraki aşamasında Türkiye'de kentsel tarımın çerçevesi tartışlacaktır.

\section{Kentsel Tarım Çerçevesi}

Türkiye'de kentsel tarım uygulamaları ve araştırmalarında ana çerçeveyi oluşturan kurallar, tanımlar ve uygulama örneklerinde önemli eksiklikler bulunmaktadır. Bu kapsamda kentsel tarım için bütüncül bir çerçeve oluşturma sürecinde yapısal ve oluşumsal çerçeve olarak iki tamamlayıcı aşama ayrıntılandırılacaktır.

\section{Yapısal Çerçeve ${ }^{8}$}

Kentsel tarımın Türkiye'de yapısal çerçevesi mevzuat, planlar ve bağlayı̊ı belgeler analizine dayanmaktadır. Bu kapsamda yapısal çerçeve, kentsel tarım ile doğrudan ya da dolaylı ilişki kurulabilecek mevzuat, strateji-politika belgeleri ve ilgili planların analizinden oluşmaktadır (Ankara Kalkınma Ajansı, 2020a).

Bu kapsamda özellikle planlar ve strateji belgeleri incelemesinde kent ölçeğinde Ankara ve ilçe ölçeğinde Çankaya örnek ölçekler olarak analiz edilmiştir. Kentsel tarımın yapısal çerçevesi olarak belirlenen değerlendirmeler için AnkaraÇankaya'nın seçilmesinin birkaçönemli nedeni vardır; daha yaşanabilir, ekolojik açıdan zengin, kendi kendine yetebilen ve üretebilen, herkes için erişilebilir, tüm

\footnotetext{
${ }^{7}$ Savunma tarlaları ya da savaş bahçeleri olarak da bilinen Zafer Bahçeleri Birinci ve İkinci Dünya Savaşları sırasında İngiltere, ABD, Kanada, Avustralya ve Almanya'da baharat, sebze ve meyve yetiştirmek üzere kurulan bahçelere verilen isimdir.

${ }^{8}$ Makalenin '3.1. Yapısal Çerçeve' başlığı altındaki araştırmalar hazırlanırken, bu makale yazarlarının yer almış olduğu Ankara Kalkınma Ajansı'nın 2020'de yayınladığı “Kentsel Tarım Stratejisi Belgesi Çankaya Ilçesi Uygulama Örneği” isimli araştırma projesinden kısmi olarak faydalanılmıştır.
} 
sakinlerin yaşam kalitesi üzerinde yüksek bir etkiye sahip kentsel mekanlara örnek olarak kentsel tarım uygulamaları gelmektedir. Bu uygulamaları analiz etmek için de Türkiye'nin ve başkentin merkezi olan Çankaya İlçesi uygun görülmüştür. Yaklaşık bir milyon nüfusa ev sahipliği yapan Çankaya, Ankara'nın merkez ilçesidir. İlçedeki 65 yaş üstü nüfus ülke ortalamasının üzerine iken aynı zamanda eğitim kurumlarının bölgede yoğunlaşması sebebi ile çocuk ve genç nüfus da yüksektir. Belirtilen gruplar hem hobi hem de eğitim amaçlı kentsel tarım uygulamalarında aktif rol alabilecek potansiyele sahiptirler. Bunun yanında ilçede halihazırda uygulanan kentsel tarım girişimleri de bulunmaktadır.

Mekansal olarak Çankaya İlçesinde batı kesimde yer alan yerleşim alanlarının müstakil ve yarı müstakil konutları barındırması, konut bahçelerinde kentsel tarım uygulamalarının yapabilme potansiyelini artırmaktadır. Bunun yanında Çankaya İlçesi'nin merkezi çekirdek alanın, hizmet sektörü yoğun karakteri nedeniyle kalabalık ve yoğun olan alanında ise kentsel tarım uygulamalarından dikey tarım, yeşil çatılar, okul ve kamu arazilerinin kentsel tarım için kullanılabilme potansiyeli ve bölgedeki boş araziler kentsel tarım uygulamaları için düşünülebilir. Ek olarak, Çankaya İlçesi'nde, Kurtuluş ve Bademlidere parklarının yanı sıra Dikmen Vadisi Rekreasyon Alanı ve İncesu ve Cevizlidere gibi caddeler üzerinde bulunan yeşil alanlar potansiyel kentsel tarım alanları olarak öne çıkmaktadırlar.

Covid-19 salgını sonrası toplumlar yeni çözüm arayışlarına girmiş kamusal parklar, kentsel tarım alanları gibi mekanlar önem kazanmıştır. Yerel yönetimlerin de desteklemesinin önemli olduğu bu süreçte Çankaya Belediyesi gerçekleştirdiği girişimler ile öncü ve bu konuda örnek gösterilebilecek kolaylaştırıc bir belediyedir. Bunun yanında diğer kamu kurumlarının ve sivil toplum örgütlerinin süreçte kentsel tarım konusundaki farkındalıkları gün geçtikçe artmaktadır. Çankaya İlçesi ayrıca mahalle örgütlenmelerinin ve bu örgütlerin kentsel tarımla ilgili girişimlerinin bulunmasıyla da örnek olarak gösterilmektedir. Dolayısı ile tüm bu potansiyellerden dolayı Ankara-Çankaya kentsel tarımın yapısal çerçevesi olarak tanımlanan bağlamda değerlendirilmeye uygun görülmüştür.

\section{Mevzuat Analizi}

Kentsel tarım ile ilişkili uygulamaya konabilecek geliştirici ve ileriye dönük adımlar atılabilmesi için genel kurallar ve ilkelerin olduğu kapsamı açıklamak önemlidir. Bu çerçevede, kentleşme mevzuatında ve tarımsal üretim mevzuatında kentsel tarım şeklinde iki başlık altında Tablo 1'deki belirtildiği şekliyle analiz edilecektir. 
Kırsal kalkınma ve tarım politikaları kentsel gelişimin ve planlamanın öncelikli çalışma alanlarından biridir. Birbiri ile iç içe olan kentleşme ve tarımsal üretim konuları kentsel tarım araştırması bağlamında ayrı mevzuat incelemeleri olarak burada çalışılacaktır. Türkiye'de tarım konusunda kuralları ortaya koyan bu belgelerde doğrudan kentsel tarımı işaret eden düzenlemeler bulunmazken, kentsel tarım stratejilerini etkileyebilecek dolaylı kurallar çıkarrlabilmektedir. Tablo 1'de öncelikle T.C. Anayasası'nda tarım ile ilgili maddeler incelenmiştir.

Tablo 1. Kentsel Tarım Bağlamında Kentleşme ve Tarımsal Üretim Mevzuat Analizi

\begin{tabular}{lllll}
\hline Yasal Belge & \multicolumn{2}{l}{$\begin{array}{l}\text { Tarihi/ } \\
\text { Numara }\end{array}$} & $\begin{array}{l}\text { Tarım/Kentsel Tarım/ } \\
\text { Kursal Kalkınma ile İlişkilendirilen } \\
\text { Madde ve Içeriği }\end{array}$ & $\begin{array}{l}\text { Kentsel Tarım } \\
\text { Bağlamında } \\
\text { Maddenin Anlamı }\end{array}$ \\
\hline $\begin{array}{l}\text { T.C. Anaya- } \\
\text { sası }\end{array}$ & $\begin{array}{l}1982 \\
2709 \\
\text { ralı }\end{array}$ & $\begin{array}{l}\text { tarihli, } \\
\text { numa- }\end{array}$ & $\begin{array}{l}\text { Madde 45: Tarımsal üretimin etkinli- } \\
\text { ğini artırmak için tarım, hayvancllkk } \\
\text { ve bu üretim dallarında çalışanların } \\
\text { korunması. }\end{array}$ & $\begin{array}{l}\text { Tarım alanların koru- } \\
\text { mak, tarımsal üretimi } \\
\text { teşvik etmek }\end{array}$ \\
\cline { 3 - 5 } & & $\begin{array}{l}\text { Madde 166: Sanayi ve tarımın dengeli } \\
\text { ve uyumlu gelişiminin sağlanması. }\end{array}$ & $\begin{array}{l}\text { Devletin görevi olarak } \\
\text { tarımsal gelişimin des- } \\
\text { teklenmesi }\end{array}$ \\
\hline
\end{tabular}

TARIMSAL ÜRETIM MEVZUATINDA KENTSEL TARIM

\begin{tabular}{|c|c|c|c|c|c|}
\hline \multirow[t]{4}{*}{$\begin{array}{l}\text { Tarum } \\
\text { nunu }\end{array}$} & \multirow[t]{4}{*}{ Ка- } & \multirow[t]{4}{*}{$\begin{array}{l}2006 \\
5488 \\
\text { ralı }\end{array}$} & \multirow[t]{4}{*}{$\begin{array}{l}\text { tarihli, } \\
\text { numa- }\end{array}$} & $\begin{array}{l}\text { Madde 2: Tarım politikalarının amaç, } \\
\text { kapsam ve konularının belirlenmesi; } \\
\text { gerekli programlarını ve Ar-Ge dü- } \\
\text { zenlemelerinin tanımlanması. }\end{array}$ & $\begin{array}{l}\text { Tarımsal faaliyetlerin ge- } \\
\text { nel ilkeleri }\end{array}$ \\
\hline & & & & $\begin{array}{l}\text { Madde 4: Tarım politikalarının amaç- } \\
\text { ları tarımsal üretimin geliştirilmesi, } \\
\text { kaynakların korunması, verimliliğin } \\
\text { artırılması, gida güvencesi, üretici ör- } \\
\text { gütlerinin geliştirilmesi, tarımsal piya- } \\
\text { saların güçlendirilmesi, kırsal kal- } \\
\text { kınma }\end{array}$ & $\begin{array}{l}\text { Tarım politikaların ilgi- } \\
\text { lendiren bir karar verilir- } \\
\text { ken amacın ne olması ge- } \\
\text { rektiğini belirten ve içeri- } \\
\text { ğindeki konular kapsa- } \\
\text { mında kentsel tarım ile } \\
\text { ilişkilendirilebilecek } \\
\text { madde }\end{array}$ \\
\hline & & & & $\begin{array}{l}\text { Madde 6: Tarım politikalarının önce- } \\
\text { likleri (verimlilik, ürün çeşitliliği, ka- } \\
\text { lite, güvenilir gıda, teknoloji ve bilgi } \\
\text { sistemlerinin kullanımı, üretici örgüt- } \\
\text { lenmeleri, toprak ve su kaynaklarının } \\
\text { rasyonel kullanılması. }\end{array}$ & $\begin{array}{l}\text { Kentsel tarımı ima eden } \\
\text { konuların öncelikli oldu- } \\
\text { ğunun vurgulanması }\end{array}$ \\
\hline & & & & $\begin{array}{l}\text { Madde 8: Tarımsal bilgi teknolojileri- } \\
\text { nin adaptasyonu, Ar-Ge faaliyetleri } \\
\text { yapılması ve bu konularda kurumsal } \\
\text { iş birliği sağlanması. }\end{array}$ & $\begin{array}{l}\text { Tarımsal Ar-Ge'nin ge- } \\
\text { nel çerçevesini belirleyen } \\
\text { madde; kentsel tarım da } \\
\text { modern tarım teknikleri- } \\
\text { nin kullanılabileceği, } \\
\text { yeni araştırma yöntemle- } \\
\text { rinin uygulanabileceği }\end{array}$ \\
\hline
\end{tabular}


bir alan olduğu düşünülürse bu bağlamın genel çerçevesini çizen madde

Madde 15: Kırsal alanlarda eğitim düzeyi yükseltilerek istihdamın geliştirilmesi, kırsal kalkınma program ve projelerinin geliştirilmesi (katılımallk ve tabandan yukarı yaklaşım ile).

Madde 19 Tarımsal destekleme araçları:

e) Kırsal kalkınma destekleri: Kırsal kalkınma ve yatırım projelerine, istihdam artırıc girişimlere devlet desteği ve temel ilkeler olarak paydaş katılımı, tabandan yukarı yaklaşım, sürdürülebilirlik, modern işletmecilik sistemlerinin kullanım.

Kırsal kalkınmanın temel ilkelerini belirten madde; özellikle tarımsal müdahalelerde katilımcllik vurgusunun kentsel tarım konusunda dayanak oluşturabilmesi

Kırsal kalkınma projelerinde maliyet finansmanında devlet desteğinin genel çerçevesi; kentsel tarım için önemli anahtar kelimeler olarak katilımcllk sürdürülebilirlik ve tarımda modern işletmecilik.

\begin{tabular}{llllll}
\hline Organik Ta- & 2004 & tarihli, & Madde 3(b): Organik tarım üretim fa- & Kentsel tarım bağla- \\
rum Kanunu & 5262 & numa- & $\begin{array}{l}\text { aliyetlerinin özellikleri (doğal alan- } \\
\text { minda organik tarımın }\end{array}$ \\
& ralı & & $\begin{array}{l}\text { larda doğal kaynaklar kullanılarak ve } \\
\text { tedarik zincirindeki temel işlemler). }\end{array}$ & $\begin{array}{l}\text { önemli konulardan biri } \\
\text { olması }\end{array}$
\end{tabular}

\begin{tabular}{|c|c|c|c|c|}
\hline \multirow[t]{5}{*}{$\begin{array}{l}\text { Toprak Ko- } \\
\text { ruma ve } \\
\text { Arazi Kulla- } \\
\text { nımı Kanunu }\end{array}$} & \multirow[t]{5}{*}{$\begin{array}{l}2005 \\
5403 \\
\text { ralı }\end{array}$} & \multirow[t]{5}{*}{$\begin{array}{l}\text { tarihli, } \\
\text { numa- }\end{array}$} & $\begin{array}{l}\text { Madde 3: Tarım arazisi, mutlak tarım } \\
\text { arazisi, özel ürün arazisi, dikili tarım } \\
\text { arazisi, marjinal tarım arazisi, yeter } \\
\text { büyüklükte tarımsal arazi parseli, ta- } \\
\text { rım dışı alanlar, sulu tarım arazisi kav- } \\
\text { ramlarının tanımları. }\end{array}$ & $\begin{array}{l}\text { Tarımsal arazi çeşitlerini } \\
\text { tanımlayan madde, kent- } \\
\text { sel tarım alanı/arazisi ya } \\
\text { da ima eden bir tanım } \\
\text { bulunmamaktadır. }\end{array}$ \\
\hline & & & $\begin{array}{l}\text { Madde 8: Tarım arazilerinin sınıflan- } \\
\text { dırılması ve arazi parsel büyüklükleri- } \\
\text { nin belirlenmesi. Bölünebilecek en kü- } \\
\text { çük alan büyüklüğü }\end{array}$ & $\begin{array}{l}\text { Kentsel tarımın yapılabi- } \\
\text { leceği en küçü̈ arazi } \\
\text { parselinin Bakanlı tara- } \\
\text { fından belirlenebileceği; } \\
\text { bu minimum tarımsal } \\
\text { arazi büyüklüğünün al- } \\
\text { tında bölünemeyeceği } \\
\text { anlamı. }\end{array}$ \\
\hline & & & $\begin{array}{l}\text { Madde 9: Toprakların korunması, do- } \\
\text { ğal ve yapay olaylar karşısında toprak } \\
\text { kayıplarını önlenmesi. }\end{array}$ & $\begin{array}{l}\text { Kentsel tarımda toprağın } \\
\text { korunması ile ilgili genel } \\
\text { çerçeveyi ortaya koyabi- } \\
\text { lecek dayanak madde }\end{array}$ \\
\hline & & & $\begin{array}{l}\text { Madde 10: Arazi kullanım planlarını } \\
\text { yapılması, yetkisi, içeriği ve bu ko- } \\
\text { nuda sürdürülebilir kalkınma ilkesi } \\
\text { vurgusu. }\end{array}$ & $\begin{array}{l}\text { Kentsel tarımın da bir ta- } \\
\text { rımsal arazi türü olarak } \\
\text { belirtilen planlarda bulu- } \\
\text { nabilme potansiyeli. }\end{array}$ \\
\hline & & & $\begin{array}{l}\text { Madde 11: Tarımsal amaçlı arazi kul- } \\
\text { lanım plân ve projelerinin hazırlan- } \\
\text { ması ve amacı, bu süreçte çiftçilerin ve }\end{array}$ & $\begin{array}{l}\text { Kentsel tarım konu- } \\
\text { sunda yaplacak bir plan } \\
\text { ya da proje sürecinin ge- }\end{array}$ \\
\hline
\end{tabular}


arazi sahiplerinin görüşleri alınmasınun kanunla garanti altına alınmış olmasi.

\begin{tabular}{|c|c|c|}
\hline $\begin{array}{l}\text { Tarumsal } \\
\text { Üretici Birlik- } \\
\text { leri Kanunu }\end{array}$ & $\begin{array}{l}2004 \text { tarihli, } \\
5200 \text { numa- } \\
\text { ralı }\end{array}$ & $\begin{array}{l}\text { Madde 1: Tarımsal üretimin genel çer- } \\
\text { çevesi ve tarımsal üretici birliklerinin } \\
\text { kurulması }\end{array}$ \\
\hline $\begin{array}{l}\text { Çevresel Etki } \\
\text { Değerlendir- } \\
\text { mesi Yönet- } \\
\text { meliği }\end{array}$ & $\begin{array}{ll}2014 & \text { tarihli, } \\
28186 & \text { Resmî } \\
\text { Gazete Sayısı }\end{array}$ & $\begin{array}{l}\text { Ek } 5 \text { (3b): Tarımsal alanların korun- } \\
\text { ması }\end{array}$ \\
\hline
\end{tabular}

\begin{tabular}{|c|c|c|c|}
\hline \multirow[t]{3}{*}{$\begin{array}{l}\text { Hobi Bahçe- } \\
\text { leri ile ilgili il } \\
\text { ölçeğinde ör- } \\
\text { nek yönet- } \\
\text { melikler }\end{array}$} & $\begin{array}{l}\text { Antalya Bü- } \\
\text { yükşehir Be- } \\
\text { lediyesi Hobi } \\
\text { Bahçeleri İş- } \\
\text { letme Yönet- } \\
\text { meliği }\end{array}$ & $\begin{array}{l}\text { Madde 1: Yönetmeliğin amac kentte } \\
\text { yaşayanların doğada zaman geçir- } \\
\text { mesi, ürün yetiştirmesi ve hobi tatmi- } \\
\text { niyetini sağlamak }\end{array}$ & \multirow{3}{*}{$\begin{array}{l}\text { Hobi bahçeleri bireysel } \\
\text { olarak kentsel alanda ya } \\
\text { da kent çeperinde küçük } \\
\text { ölçekli tarım yapılması } \\
\text { amacıyla kullanılan özel } \\
\text { mülkiyetli küçük arsalar- } \\
\text { dır ve kentsel tarımı ilgi- } \\
\text { lendiren başlıklardan bi- } \\
\text { ridir. Yasal mevzuatta } \\
\text { hobi bahçeleri ile ilgili } \\
\text { düzenleme içeren bir ku- } \\
\text { rala rastlanmamaktadır. } \\
\text { Yönetmelik çkarma yet- } \\
\text { kisini kullanarak bazı ye- } \\
\text { rel yönetimler kendi } \\
\text { idari sınırlarını ilgilendi- } \\
\text { recek kapsamda hobi } \\
\text { bahçeleri ile ilgili temel } \\
\text { kurallar belirlemektedir- } \\
\text { ler. }\end{array}$} \\
\hline & $\begin{array}{l}\text { Balıkesir Bele- } \\
\text { diyesi Hobi } \\
\text { Bahçeleri Uy- } \\
\text { gulama ve } \\
\text { Kullanma Yö- } \\
\text { netmeliği }\end{array}$ & $\begin{array}{l}\text { Madde 1: Balıkesir Belediyesi tarafın- } \\
\text { dan yaptırılan ve hizmete sunulan } \\
\text { hobi bahçelerinin tahsis, kullanım ve } \\
\text { işletme esaslarını belirlemektir. }\end{array}$ & \\
\hline & $\begin{array}{l}\text { Afyonkarahi- } \\
\text { sar Belediyesi } \\
\text { Hobi Bahçesi } \\
\text { Tahsis veKul- } \\
\text { lanma Yönet- } \\
\text { meliği }\end{array}$ & $\begin{array}{l}\text { Madde 1: Kentte yaşayanların boş za- } \\
\text { manlarının değerlendirmek, aile büt- } \\
\text { çelerine katkıda bulunmak, hobi tat- } \\
\text { miniyeti, apartman hayatının ve kala- } \\
\text { balık şehir yaşantısının şehir halkına } \\
\text { kazandırdığı gerilimi ve stresi atabil- } \\
\text { mek, üretmenin hazzını sunmak, yeşil } \\
\text { alan kültürünün edinilmesi amaçla- } \\
\text { rıyla kapsamın belirlenmesi }\end{array}$ & \\
\hline
\end{tabular}

nel esasları ve katılımc1lık vurgusu için potansiyel dayanak madde

Kentsel tarımda olası üretici birlikleri durumu için dikkate alınabilecek madde

Tarım alanlarının korunmasinı garanti eden madde ve kentsel tarım uygulamalarınin da tarımsal alanlarda gerçekleştiği düşünülürse önemli dayanak madde.

Hobi bahçeleri bireysel olarak kentsel alanda ya da kent çeperinde küçük ölçekli tarım yapılması amaciyla kullanılan özel mülkiyetli küçük arsalardır ve kentsel tarımı ilgilendiren başlıklardan biridir. Yasal mevzuatta hobi bahçeleri ile ilgili düzenleme içeren bir kurala rastlanmamaktadır. ma yetbazı yeer kendi sinurlannı ilgilendirecek kapsamda hobi bahçeleri ile ilgili temel urallar belirlemektedir-

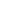

\begin{tabular}{|c|c|c|c|}
\hline \multicolumn{4}{|c|}{ KENTLEŞME MEVZUATINDA KENTSEL TARIM } \\
\hline Yasal Belge & $\begin{array}{l}\text { Tarih/ } \\
\text { Numara }\end{array}$ & $\begin{array}{l}\text { Tarım / Kentsel Tarım / Kırsal } \\
\text { Kalkınma ile İlişkilendirilen Madde } \\
\text { ve İçeriği }\end{array}$ & $\begin{array}{l}\text { Kentsel Tarım } \\
\text { Bağlamında Maddenin } \\
\text { Anlamı }\end{array}$ \\
\hline İmar Kanunu & $\begin{array}{l}1985 \text { tarihli, } \\
3194 \text { numa- } \\
\text { ralı }\end{array}$ & $\begin{array}{l}\text { Madde } 8 \text { (c): Tarım arazilerinin tarım- } \\
\text { sal amaç dışında kullanılamayacağı ve } \\
\text { korunması. }\end{array}$ & $\begin{array}{l}\text { Tarım arazilerinin, dola- } \\
\text { yısıyla da kentsel tarım } \\
\text { alanlarının, tarımsal üre- } \\
\text { tim için kullanılmasını } \\
\text { garanti altına alan } \\
\text { madde }\end{array}$ \\
\hline
\end{tabular}




\begin{tabular}{|c|c|c|c|c|}
\hline & \multirow[b]{2}{*}{$\begin{array}{l}2012 \\
6360 \\
\text { ralı }\end{array}$} & \multirow[b]{2}{*}{$\begin{array}{l}\text { tarihli, } \\
\text { numa- }\end{array}$} & \multirow[b]{2}{*}{$\begin{array}{l}\text { Madde 1: Yeni durumda Büyükşehir } \\
\text { statüsündeki illere bağlı ilçelerin } \\
\text { mülki sınırları içerisinde yer alan köy } \\
\text { ve belde belediyelerinin tüzel kişiliği } \\
\text { kaldırılmıs, köyler mahalle olarak, be- } \\
\text { lediyeler ise belde ismiyle tek mahalle } \\
\text { olarak bağlı bulundukları ilçenin bele- } \\
\text { diyesine katılmıştır. }\end{array}$} & \multirow[b]{2}{*}{$\begin{array}{l}\text { Büyükssehir belediyele- } \\
\text { rindeki köy ve belde be- } \\
\text { lediyeleri mahallelere } \\
\text { dönüştürülmüştür. } \\
\text { Kentsel tarımı ilgilendi- } \\
\text { ren boyutu; ilgili büyük- } \\
\text { şehir belediyesinin ma- } \\
\text { halleye dönüşen yerler- } \\
\text { deki tarımsal alanlarda } \\
\text { karar mekanizması ha- } \\
\text { line gelmiş olmasıdır }\end{array}$} \\
\hline $\begin{array}{l}\text { On Dört İlde } \\
\text { Büyükşehir } \\
\text { Belediyesi ve } \\
\text { Yirmi Yedi } \\
\text { İlçe Kurul- } \\
\text { ması ile Bazı } \\
\text { Kanun Ve } \\
\text { Kanun Hük- } \\
\text { münde Ka- } \\
\text { rarnamelerde } \\
\text { Değişiklik } \\
\text { Yapılmasına } \\
\text { Dair Kanun }\end{array}$ & & & & \\
\hline \multirow[t]{2}{*}{$\begin{array}{l}\text { Büyükşehir } \\
\text { Belediyesi } \\
\text { Kanunu }\end{array}$} & \multirow[t]{2}{*}{$\begin{array}{l}2004 \\
5216 \\
\text { ralı }\end{array}$} & \multirow[t]{2}{*}{$\begin{array}{l}\text { tarihli, } \\
\text { numa- }\end{array}$} & $\begin{array}{l}\text { Madde } 7 \text { (i): Büyükşehir Beledi- } \\
\text { yesi'nin görevi olarak sürdürülebilir } \\
\text { kalkınma, çevrenin, tarım alanlarının } \\
\text { ve su havzalarının korunması. }\end{array}$ & $\begin{array}{l}\text { Sürdürülebilir kalkınma } \\
\text { ile tarımsal üretim ilişki- } \\
\text { sini kuran ve genel ola- } \\
\text { rak tarımsal alanların ko- } \\
\text { runmasını garanti eden } \\
\text { madde. }\end{array}$ \\
\hline & & & $\begin{array}{l}\text { Madde } 7 \text { (ek fikra): Büyükş̧ehir ve ilçe } \\
\text { belediyelerinin tarım ve hayvancilı̆ı } \\
\text { destekleme yetkisi. }\end{array}$ & $\begin{array}{l}\text { Büyükssehir Belediyeleri- } \\
\text { nin tarımı, dolayısıyla da } \\
\text { muhtemel kentsel tarım } \\
\text { uygulamalarını destekle- } \\
\text { yebileceğini garanti eden } \\
\text { madde. }\end{array}$ \\
\hline $\begin{array}{l}\text { Belediye Ka- } \\
\text { nunu }\end{array}$ & $\begin{array}{l}2005 \\
5393 \\
\text { ralı }\end{array}$ & $\begin{array}{l}\text { tarihli, } \\
\text { numa- }\end{array}$ & $\begin{array}{l}\text { Madde 69: Belediyenin görevi olarak } \\
\text { tarım arazileri hariç imarlı arsalar üret- } \\
\text { mek. }\end{array}$ & $\begin{array}{l}\text { Arsa ve konut üretirken } \\
\text { tarım alanlarını hariç } \\
\text { tutulacağını garanti al- } \\
\text { tına alan ve dolaylı ola- } \\
\text { rak muhtemel kentsel ta- } \\
\text { rım alanlarının da tarım- } \\
\text { sal arazi statüsü edindiği } \\
\text { durumda korunacağını } \\
\text { belirten madde. }\end{array}$ \\
\hline $\begin{array}{l}\text { Plansiz Alan- } \\
\text { lar İmar Yö- } \\
\text { netmeliği }\end{array}$ & $\begin{array}{l}1985 \\
18916 \\
\text { Gazete }\end{array}$ & $\begin{array}{l}\text { tarihli, } \\
\text { Resmî } \\
\text { Sayısı }\end{array}$ & $\begin{array}{l}\text { Madde } 4 \text { ( } 30 \text { ve } 33 \text {. bendleri): Tarım } \\
\text { arazisine tarımsal amaçlı yapı yapıl- } \\
\text { masında izin durumu ve kuralları ve } \\
\text { yapının tanımı }\end{array}$ & $\begin{array}{l}\text { Kentsel tarım alanına } \\
\text { yapı yapılmak istendi- } \\
\text { ginde dikkate alınması } \\
\text { gereken madde. }\end{array}$ \\
\hline
\end{tabular}

\begin{tabular}{|c|c|c|c|}
\hline 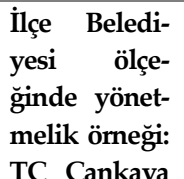 & $\begin{array}{l}\text { Çankaya Be- } \\
\text { lediyesi }\end{array}$ & $\begin{array}{l}\text { Madde } 11 \text { (1): Kent Tarım Hizmetleri } \\
\text { Bürosu'nun ilgili birim altında kurul- } \\
\text { ması }\end{array}$ & $\begin{array}{l}\text { Kentsel tarım uygulama- } \\
\text { larından sorumlu bir bi- } \\
\text { rimin belediye içerisinde } \\
\text { yer alabilmesi örneği }\end{array}$ \\
\hline
\end{tabular}




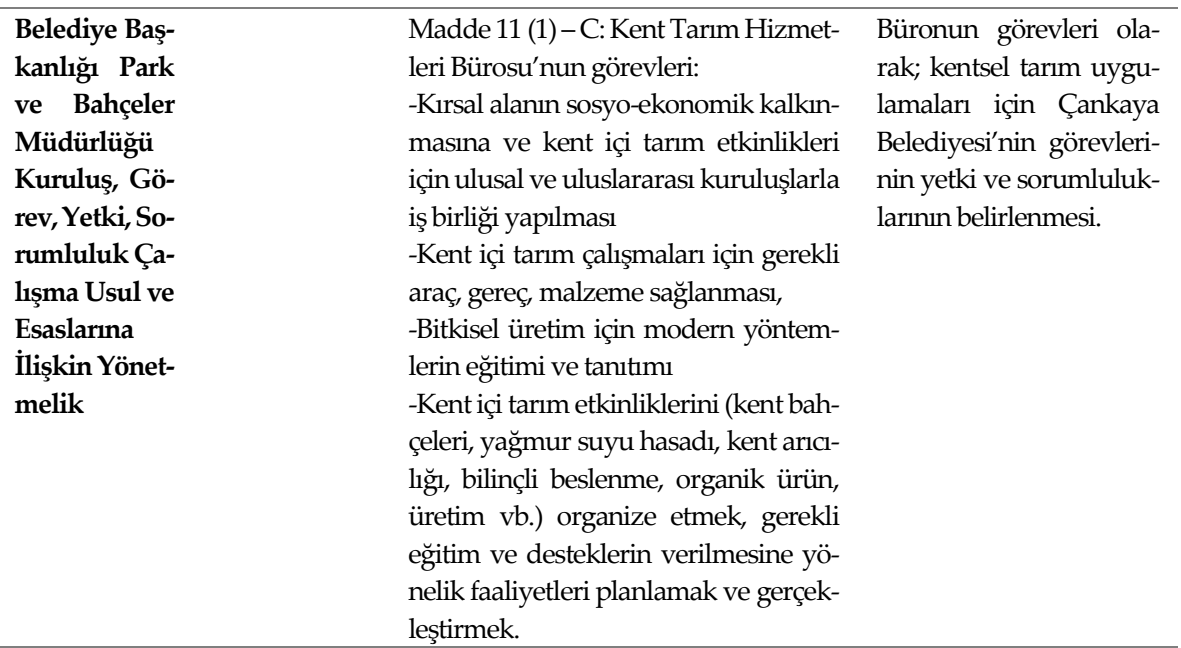

T.C. Anayasası'nda tarımsal üretimin önemi ve desteklenmesi ile ilgili üst çerçeve maddeler bulunmaktadır. Bu çerçeveye uygun olarak tarımsal üretim ve kentleşme mevzuatındaki ilgili belgeler incelenmiştir. Tarımsal üretim mevzuatı kapsamında ele alınan belgelerin içeriğindeki konular iki başlık altında toplanabilir. Bunlar, tarım alanlarının korunması ve kentsel tarım ile ilişkilendirilebilecek anahtar kavramlardır. Tarım alanlarının korunması kapsamında; tarımsal faaliyetlerin genel ilkeleri, kırsal kalkınmanın önemi, toprağın ve tarımsal faaliyet yapılan alanların korunması ile ilgili içerikler bulunmaktadır. Bu genel kurallar kentsel tarıma dayanak oluşturması açısından önemlidir. İkinci başlık olan kentsel tarım ile ilişkilendirilecek anahtar kavramlar kapsamında çeşitli yasal belgelerden gelen, direkt kentsel tarıma yönelik olmasa da muhtemel kentsel tarım müdahaleleri için potansiyel olarak öne çıkan kavramlar ortaya koymaktadır. Bu anahtar kavramlar; tarımsal ArGe, katılımcılık, üretici birlikleri oluşturulması, organik tarım, hobi bahçeleri, gıda güvencesi ve bilgi teknoloji hizmetlerinin kullanılmasıdır. Bu kavramların tarımsal üretim ile ilişkisini incelenen mevzuat kurabilmektedir. Direkt kentsel tarım ile açıkça ilişkilendirilmese de kentsel tarımın yapısal çerçevesi için önemli potansiyel girdiler sağlamaktadır.

Kentleşme mevzuatı incelendiğinde ise kentsel gelişimin ve kalkınmanın tarım konusu ile kurduğu ilişki odak alınarak analiz yapılmıştır. Bu kapsamda, genel kanun ve yönetmelikler incelendiğinde, kentsel tarımı direkt konu alan maddelerin bulunmadığı; ancak tarımsal arazilerin korunması ve tarımsal üretimin desteklenmesini konu alan ifadeler bulunduğu görülmüştür. Bunun yanında ele alınan Çankaya ilçe belediyesi örneği için incelenen 
yönetmelikte açıkça kentsel tarım ile ilgili çalışacak bir birimin ilçe belediyesi bünyesinde kurulabileceği ve görev ve yetkilerin açıkça tanımlanabileceği görülmektedir.

Sonuç olarak, tarımsal üretim ve kentleşme mevzuatında çoğunlukla kentsel tarım ile dolaylı olarak ilişkilendirilebilecek kurallar yer almaktadır. Yapısal çerçevenin tamamlayıcısı olarak strateji ve politika belgeleri ve planların analizi kentsel tarım ile ilişkili özellikle bölgesel ve yerel ölçekte önemli girdiler ortaya koymaktadir.

\section{Planlarda ve Bazi Strateji Belgelerinde Kentsel Tarm}

Strateji belgeleri ve planlar incelemesinde Ankara (kent ölçeğinde) ve Çankaya (ilçe ölçeğinde) örnek ölçekler olarak analiz edilmiştir. Bu kapsamda, kentsel tarım ile doğrudan ya da dolaylı biçimde ilişkilendirilebilecek kısımlar belirtilmiştir. Yapılan incelemede Dokuzuncu Kalkınma Planı (20072013) Özel İhtisas Komisyon Raporları-Yerleşme ve Şehirleşme Raporu'nda geçen kentsel tarım tanımı ve 2023 Başkent Nazım İmar Planı içeriğinde AOÇ ile ilgili alınan kararların en belirgin ve kentsel tarım ile ilişkilendirilebileceği öngörülmüştür.

Dokuzuncu Kalkınma Planı - Yerleşme ve Şehirleşme Özel İhtisas Komisyonu Raporu

Plan ve strateji belgelerinde kentsel tarımın tanımı ve kapsamı net olarak yer almamaktadır. Ancak ilk kez, tanımlamaya yaklaşan ve mevzuatta düzenlemeler yapılması gerekliliğini ortaya koyan ifade Dokuzuncu Kalkınma Planı (2007-2013) Özel İhtisas Komisyon Raporları-Yerleşme ve Şehirleşme Raporu kapsamında kendine yer bulmuştur (Devlet Planlama Teşkilatı, 2007). Kalkınma Planı kapsamındaki bu raporda 'mevzuat düzenlemeleri' bölümündeki kentsel tarım ile ilgili ifade şu şekildedir:

"Kentsel tarımla ilgili (topluluk bahçeleri (community gardens), tahsisli bahçeler ya da hobi bahçeleri (allotment gardens veya allotments), çatı bahçeleri (rooftop gardens), kent çiftlikleri (city farms), çocuk kent ç̧ftlikleri (children's city farms) v.b. kullanım biçimleri konusunda ö̈celikle terminolojinin ayrıştırlması ve netleștirilmesi ve kent imar planlarında da gö̈terimler kısmında yer bulabilmesi gereklidir."

Kalkınma Planı Türkiye'de planlama hiyerarşisinde en üstte yer alması nedeniyle, bu planda kentsel tarım terimini açıklamaya yönelik çalışmalar ve bu amaçla ilgili ifadede yönlendirmeler yapılması bağlayıcı etkisi nedeniyle oldukça olumludur. Daha alt ölçekli kentsel planlar için de bu detaylandırılmış terminolojide çalışılması gerektiği belirtilmiştir. 


\section{Başkent Nazım Imar Planı}

Üst ölçek planlarla alt ölçek uygulama plan ve projeleri arasında geçiş ölçeği olarak kullanılan bir kentsel plan olan 2023 Başkent Nazım İmar Planı'nda kentsel tarım ya da bostan ile ilgili tanım ya da açıklama yer almamaktadır. Bunun yanında planda, kuruluşunda kentsel tarım uygulamalarını da barındıran Atatürk Orman Çiftliği (AOÇ) ve kentsel tarım için önemli anahtar terimlerden olan modern tarım ile ilgili ifadeler bulunmaktadır. Plan Açıklama Raporu içerisinde 'Sosyal Yaşam' başlı̆̆ altında kentsel tarım ile ilişkilendirilebilecek şu ifadeler bulunmaktadır:

-AOÇ'nin örnek bir çiftlik olarak kurgulanması

-AOÇ ile kent halkına düşük fiyatlı ve temiz gıda sağlanması

-AOÇ'nin bu özellikleri ile bütünleşerek bir rekreasyon alanı olarak planlanması (Ankara Büyükşehir Belediyesi, 2006).

Bu kapsamda AOÇ'nin, kırsal kullanımları da içinde barındıran kentsel bir uygulama olarak tasarlandığı ve bu durumun da kentsel tarım ile ilişkilendirilebileceği belirtilebilir. Günümüzde AOÇ arazisi diğer kentsel kullanımlar için küçülerek bölünmüş durumda olsa da kentsel tarım uygulamalarının yer alabileceği önemli bir potansiyel kullanım olarak yer almaktadır.

Sosyal Yaşam başlı̆̆ altında AOÇ'nin kent içindeki konumu ve kentsel tarımın da konularından biri olan modern tarım vurgusu öne çıkmaktadır. AOÇ alanının 1. Derece Doğal ve Tarihi Sit Alanı olarak tescillenmiş kısmı içerisinde tarımsal varlığın korunarak Ar-Ge faaliyetleri ile geliştirilecek modern tarım tekniklerinin alanın rekreatif özelliğinin de ön plana çıkarılarak kullanılması planlanmaktadır.

Araştırma kapsamında analiz edilen ve kentsel tarım, modern tarım, bostan, AOÇ gibi kavramlar ile ilgili doğrudan ya da dolaylı ilişki kurulamayan plan belgeleri 10. Kalkınma Planı 2014-2018, 11. Kalkınma Planı 2019- 2023, ve Ankara Bölge Planı 2014-2023 'dır.

\section{Ankara Kalkınma Ajansı Ankara Bölgesel Yenilik Stratejisi}

Ankara Bölgesel Yenilik Stratejisi Ankara Kalkınma Ajansı tarafından 2018-2019 yılları arasında proje olarak hazırlanmıştır. İçeriğinde doğrudan kentsel tarımı işaret eden ifadeler bulunmasa da kentsel tarımın alt konularından olan akıllı tarım ve lojistik uygulamaları ve tarımsal Ar-Ge faaliyetleri yer almaktadır. Aynı zamanda, belge içeriğinde tarımsal üretimin önemi ve 
tarımın Ankara için en öncelikli beş kalkınma sektöründen biri olduğu vurgulanmaktadır (Ankara Kalkınma Ajansı, 2020b).

\section{Çankaya Sağllklı Kent Projeleri 2014-2019}

Çankaya Belediyesi'nin gerçekleştirdiği kentsel tarım girişimlerini içeren bu çalışmada sağlıklı kent temalı ‘Mutlukent Mahalle Bostanı ve Kent Tarım Hobi Evi' örneği bulunmaktadır. Kurulmuş olan Kent Tarım Hobi Evi'nde alanda yaşayan insanlar için tarımsal ürün yetiştirme ve bahçıvanlık gibi konularda bilgilendirici kuramsal ve uygulamalı eğitimler verilmektedir (Çankaya Belediyesi, 2019a).

\section{Çankaya Belediyesi 2020-2024 Stratejik Planı}

Bu planda vurgulanan altı öncelikli amaçtan dördüncüsü şu şekilde ifade edilmiştir: "Bütün canlılara saygıll, yaşam kalitesini artıran sosyal, ekonomik ve çevre sorunlarına kahıcı çz̈zümler üreten temiz bir Çankaya". Bu çerçevede belirlenen yedi alt hedeften 'Hedef 4.5' teki ifade kentsel tarımın alt konu başlıklarından birine işaret etmektedir: "Organik tarımı özendirmek ve organik ürünlere erişimi kolaylaştıracak faaliyetler yapmak". Planda bunun gibi alt hedefler yapılabilecek faaliyetlerle desteklenmektedir. Hedef 4.5 çerçevesindeki alt faaliyetler bahçıvanlık ve tarım eğitimleri gerçekleştirilmesi ve organik tarım konusunda eğitim ve denetimlerin yapılması şeklinde ortaya konmuştur.

$\mathrm{Bu}$ eğitim ve faaliyetlerin gerçekleştirilebilmesi için Çankaya Belediyesi'nin ayırdığı bütçe ile uygulamalar planlanmaktadır. Faaliyetlerin açiklandığı bölümde ‘Planlı Kentleşme ve Mekânsal Gelişim Faaliyetler' konusunun altında 'Kentsel Tarım Çalışmaları' ifadesiyle belirtilen faaliyetlerin açıklandığı ve paydaşların belirlendiği bir bölüm de yer almaktadır. Çalışmada kentsel tarım uygulamalarının daha sıklaşması, gelişkin hale gelmesi ve elde edilen ürünlerin tüketicinin faydası için kullanılmasının öneminden 'Pestle Analizi' (Çevre Analizi) konusu altında bahsedilmektedir. Kentsel tarım ile doğrudan ilişki kurulan ve yapılması gerekenler konusunda fikir veren ifade şu şekildedir: "...tarımsal alanları koruyan ve geliştiren planlar yapılarak tarımsal projeler geliştirmek...". Çalışmada aynı zamanda, sorumluluk altındaki idari sınırlar içerisinde yaratılabilecek fırsatlar tanımlanmıştır. Bu kısımda, var olan kentsel tarım potansiyeli "kent tarımı ve tarımsal üretim için geniş alanların olması" ifadesiyle belirtilmektedir (Çankaya Belediyesi, 2019b). Bir ilçe belediyesi için önemli ölçüde yol gösterici bir strateji dokümanı olan bu stratejik plan kentsel tarım stratejileri için açıkça kentsel tarıma vurgu yapan önemli bir örnektir. 
İncelenen strateji-politika belgeleri ve planlar arasında kentsel tarım ile ilgili doğrudan ya da dolaylı kurulabilecek ilişkiye rastlanmayan belgeler şunlardır: Tarım Ve Kırsal Kalkınmayı Destekleme Kurumu 2019-2023 Stratejik Planı, Tarım Orman Bakanlığı - Stratejik Plan 2018-2022, Tarım Orman Bakanlığ1 - Stratejik Plan 2019-2023, Tarım ve Orman Bakanlığ 2018 Faaliyet Raporu, Yeni Ekonomik Program 2019-2021 ile Birleşmiş, Milletler Sürdürülebilir Kalkınma Hedefleri 2030, Kırsal Kalkınma Eylem Planı 2015-2018, Gıda Tarım Hayvancılık Bakanlığı 2018-2022 Stratejik Planı, Gıda Tarım ve Hayvancllık Bakanlığı-Ulusal Kırsal Kalkınma Stratejisi 2014-2020, Gıda Tarım ve Hayvancılık Bakanlı̆̆ Kırsal Kalkınma Eylem Planı, Ankara ili Tarımsal Yatırım Rehberi, Çankaya Kent Sağlık Göstergeleri ve Çankaya Kent Sağlık Gelişim Planı 2019-2023.

\section{Yapısal Çerçevenin Kısıtları ve Olanaklan}

Yapılan incelemelerde görülmektedir ki, kentsel tarım konusunda Ankara bağlamında dikkate değer kısıtlar bulunmaktadır. Diğer taraftan, yerel yönetimlerin kentsel tarım amacıyla gerçekleştirebilecekleri önemli müdahale alanları da bulunmaktadır. Bu belirlemeler ışığında olanaklar ve kısıtlar aşağıdaki gibi özetlenebilir:

\section{Olanaklar}

-Yönetmelik Çıkarma Yetkisi

T.C. Anayasa 124. Maddesinde kamu tüzel kişiliğine sahip olan birimlerin yönetmelik çıkarma yetkisinden bahsetmektedir. Belediyelerin de kamu tüzel kişiliği olması nedeniyle Çankaya Belediyesi ve Ankara Büyükşsehir Belediyesi gibi yerel yönetimlerin bağlayıc üst yasal normlarla çelişmeden yönetmelik çıararak yerele özgü kurallar ve sorumluluklar belirleme yetkisi bulunmaktadır. Bunun yanında 5393 Sayılı Belediye Kanunu'nun 15. Maddesinde de belediyelerin yönetmelik çıkarma yetkisinden bahsedilmektedir.

Anayasa ve kanunlara uygun olarak yerel düzeyle kuralların belirlenmesi amacıyla yönetmelik çıkarabilmek önemli bir firsattır. Kentsel tarım tanımı ve uygulamasına yönelik ifadeleri ve kuralları netleştiren yasal belge yerel düzeyde yönetmelik olabilecektir.

-Kentsel Ölçekte Plan Yapma Yetkisi

Türkiye hukuk sisteminde imar planları normlar hiyerarşisinde yönetmeliklerin üzerinde kanunların altındadır. Belediyelerin yerel yönetimler olarak mekânsal planlar hazırlama yetkisine sahip olduğu göz önüne alındığında kentsel tarım gibi stratejik öneme sahip bir konuda belirlemeler yapabilecek 
olması önemli bir araçtır. Mekânsal Planlar Yapım Yönetmeliği'nin verdiği yetkiye göre mekânsal planlamada sorumluluk dağımı, Büyükşehir Belediyeleri için Nazım İmar Planı ${ }^{9}$ ve ilçe belediyeleri için üst ölçekteki Nazım İmar Planı'na uygun olarak Uygulama İmar Planı hazırlama şeklindedir. Belirtilen her iki mekânsal plan türünü ve bunlara uygun olarak hazırlanabilecek Parselasyon Planlarını ve İmar Islah Planlarını onaylamak ilgili büyükşehir belediyesi yetkisindedir.

Yapılan bu planlar bağlayıcı önemli kurallar niteliğinde oldukları için, kentsel tarım konusunda bu planlar kapsamında atılabilecek yenilikçi strateji, politika ve projeler önemli birer potansiyel olarak öne çıkmaktadır.

-Tasarım Rehberi Hazırlamak

Mekânsal Planlar Yapım Yönetmeliği, Madde 30/7' de Tasarım Rehberi tanımlaması aşağıdaki gibi yapılmıştır:

"Kentsel tasarım projesi doğrultusunda mekânn imge, anlam ve kimlik kazanmasinı, estetik ve sanat değerinin yükseltilmesini, yapılarm bir uyum içerisinde ve bütünlük oluşturacak şekilde düzenlenmesini amaçlayan ve mekânsal planlama sistematiği içerisinde uygulamaya yönelik kulavuz ve tavsiye niteliğinde kararlar içerecek şekilde kentsel tasarım rehberi hazırlanı".

Tasarım rehberleri içerisinde kentsel tarım konusu ele alınabilmekte ve yerel ölçekte bu konuda kararlar üretilebilmektedir. Kentsel tarım müdahalelerini de içerebilecek bu tasarım rehberleri imar planının eki olarak 'Plan Açıklama Raporu' şeklinde, imar planı plan notları kapsamında ele alınarak ya da plandan ayrı, hukuki bağlayıcılığı olmayan tavsiye niteliğinde bir doküman şeklinde hazırlanabilir. Farklı ölçeklerde yerel yönetimlerden Eyüpsultan Belediyesi Kentsel Tasarım Rehberi (İlçe belediyesi örneği), Sürdürülebilir İstanbul Kentsel Tasarım Rehberi (İl belediyesi örneği) ve Ersizlerdere Köy Tasarım Rehberi (Köy Muhtarlığı girişimi örneği) örnekleri bulunmaktadir.

Kisitlar

Türkiye ölçeğinde kentsel tarım kavramından yerel yönetimler tarafından ne anlaşılması gerektiği bir tanıma ve kurala bağlanmamış durumdadır.

\footnotetext{
${ }^{9} 5216$ Sayılı Büyükşehir Belediyesi Kanunu'na göre 1/5.000 ile 1/25.000 arası ölçeklerde Nazım İmar Planı'nı yapmak, yaptırmak ve onaylamak büyükşehir belediyelerinin sorumluluğundadır. Bunun yanında, ilçe belediyeleri sorumluluklarında olan Uygulama İmar Planlarını Nazım İmar Planının yürürlüğe girmesinden itibaren en geç bir yıl içinde bu plana uygun olarak hazırlamazlarsa yetki ilgili Büyükşehir Belediyesine geçmektedir.
} 
Kentsel tarım bağlamının alt başlıkları ve alt konuları net değildir. Ankara ili ve ilçeleri çerçevesinde, yerel yönetimlerin kentsel tarım konusunda müdahale araçlarının Ankara'da neler olduğu net olarak ortaya konmamıştır. Diğer bir deyişle, Ankara'da kentsel tarım amaciyla bir girişim yapmak isteyen bireyin başvurusunu hangi makama yapacağı, ne tür kurallarla nasıl bir uygulama yapacağı belirsizliğini korumaktadır.

\section{Oluşumsal Çerçeve}

Kentsel tarım konusu coğrafi olarak tüm kenti ilgilendiren alanlarda yapılmasının yanında, bina iç mekânı gibi bir bireyi ya da topluluğu ilgilendiren alanlarda da yapılabilmektedir. Buradan yola çıkarak belirtmek gerekir ki, kentsel tarım mekânda farklı ölçeklerde gerçekleştirilerek üretim yapılabilmektedir:

- Mimari ölçekte: iç mekân, balkon, teras ve çatı üretimleri, dikey bahçeler

- Mahalle ölçeğinde: konut bahçeciliği, bostancllık, sokak kenarı (saksıda üretim), park bahçeciliği (yenilebilir peyzaj),

- Kentsel ölçekte: tahsisli bahçeler (allotment gardens), topluluk bahçeleri (community gardens), seracılık, çeper tarlaları, kent çiftlikleri, gerilla bahçeciliği, hobi bahçeleri.

Farklı ölçeklerde gerçekleşen üretim modelleri farklı mülkiyet ve işletim sistemlerine göre de tasnif edilebilmektedir. Örneğin, bahçelerde bireyler kendi üretim alanlarını işletebildikleri gibi topluluklar, belediyeler, araştırma kuruluşları, özel şirketler ve kooperatifler de kentsel tarım etkinliklerinin işletilmesi konusunda farklı modeller sunabilmektedir.

Oluşumsal çerçevede temel olarak oluş biçimi ve yöntemi önem kazanmaktadır. Bir diğer ifadeyle, yapısal çerçevede kuralları oluşturan mevzuat ve bağlayıcı plan/politika belgeleri ana çerçevenin alt parçasını oluştururken, oluşumsal çerçevede gerçekleştirilen kentsel tarım uygulamasının hangi ölçekte ve nasıl uyguladığı ana çerçevesinin diğer kısmını oluşturmaktadır. Çalışmanın bu kısmında, Türkiye'de kentsel tarım konusu, mahalle örneklem inceleme ölçeği olarak ele alınarak kentsel tarımın oluşumsal çerçevesi bağlamında değerlendirilecektir.

Kentsel tarımın oluşumsal bağlamını STK'lar, örgütsel yapılanmalar ve vatandaş inisiyatifleri oluşturmaktadırlar. Türkiye'de Çiğdemim Mahalle Bostanı, Mutlukent Bostanı, Yüzüncüyıl Berkine Elvan Bostanı, Kuzguncuk Kent Bostanı ve Yedikule Kent Bostanları bu oluşumlara örnek verilirken 
dünyada ise ABD'de Wolcott Street Farm ve Keep Growing Detroit Çiftliği, Avusturalya'da ise Perth Kent Çiftliği, örnekleri kentsel tarımın oluşumsal bağlamında değerlendirilen örneklerden olmuştur. Bu oluşumların dikkat çeken bir diğer özelliği ise her birinde bir mahalle örgütlenmesi olarak derneklerin, STK etkisi ve aracılığı ile yapılanmış olmasıdır. Dolayısı ile bu bağlamdaki kentsel tarım örneklerine geçmeden önce STK'ların kısa bir değerlendirmesinin yapılmasında fayda görülmüştür.

Günümüzde yaşanan küresel salgın koşullarında da gözlendiği üzere dünyada bir değişim ve dönüşüm gerçekleşmektedir. Buna bağlı olarak siyasal kültürün de değişmesi, çatışmacı değil uzlaşmacı bir yapıya dönüşmesi beklenmelidir. Bu konuda bireylere de eskiye oranla daha büyük roller düşmektedir. Bu yeni dünya, bireylere bir yandan daha geniş özgürlükler sağlarken, öte yandan daha geniş sorumluluklar yüklemektedir. Bu dünyanın bireylerinden beklenen yaratıcılık, katılımcılık, etkin yurttaşlık ve sorumluluk bilincidir. Kişinin toplum için sorumluluk duyması, bu yolla toplumsal sermayeye katkıda bulunması beklenmektedir. Kısaca bu birey sivil toplumun aktif bir üyesi olmalıdır. Bireylere bu yolu açan Sivil Toplum Kuruluşları (STK'lar), belli bir toplumsal hizmeti üretebilmek için küçük kamusal alanlar yaratmakta ve gerekli iradeyi oluşturmaktadır. Kendi kaynakları ve yaratıcı düşünceleriyle, vaktini ve emeğini koyarak, demokratik olarak oluşmuş bu iradeyi hayata geçiren Sivil Toplum Kuruşları, günümüz demokrasisinin yeni aktörleri olarak tanımlanmaktadır. Türkiye'de de STK'lara örnek olarak verilebilecek mahalle dernekleri bulunmaktadır. Bu derneklerden bazılarının ise kentsel tarım konusunda girişimleri bulunmaktadır. Bu derneklerden bazılarının kentsel tarım konusundaki girişimleri bu çalışma bağlamında değerlendirilecektir.

\section{Türkiye'den örnekler}

\section{Çiğdemim Mahalle Bostanı}

Kentsel tarım uygulaması olarak hayata geçirilen bu bostan Ankara'nın Çankaya İlçesinde, Çiğdem Mahallesi'nde bulunmaktadır. Çiğdemim Derneği tarafından Permankara grubunun katkı ve destekleriyle mahallede kendi doğal ürünlerini üretmek üzere yola çıkılmıştır (Şekil 1). 2012 yılında çalışmaların başladığı bu projedeki amaç; kırsalda yapılan organik, doğal ürün yetiştiriciliğinin kent merkezinde de yapılabileceğini göstermek, bu konuda toplumda bir bilinç oluşmasını sağlamak, doğal ürün yetiştiriciliği ile ilgili temel bilgileri paylaşmak, beceri kazandırmak, özellikle çocuklara ve 
gençlere ürün yetiştirme alışkanlıklarını kazandırmak, bitki türlerini tanıtmayı sağlamaktır (Çiğgdemim Mahalle Bostanı, 2020).

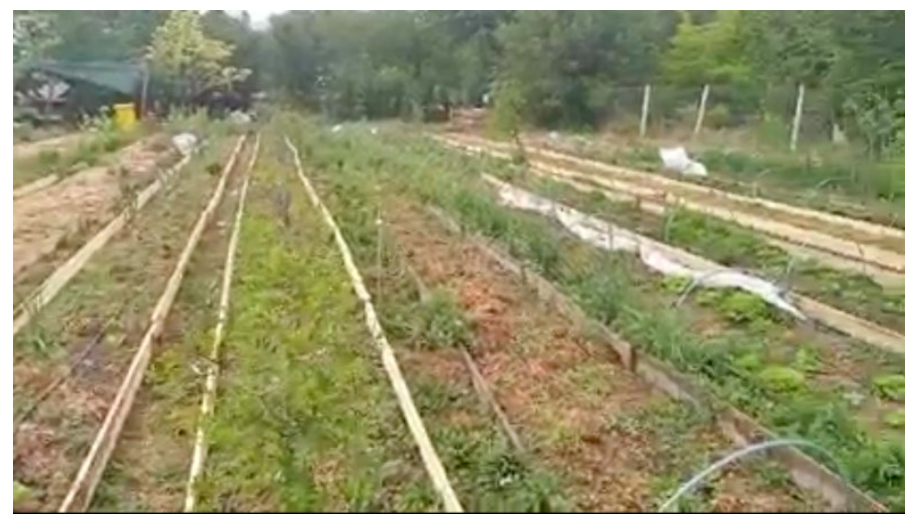

Şekil 1: Çiğdemim Mahalle Bostanı (Kaynak: Çiğdemim Derneği, 2017)

100. Yil Berkin Elvan Bostanı

Ankara'nın Çankaya İlçesi'nde, İşçi Blokları Mahallesi'nde bulunmaktadır. Mahalle hayatının dayanışmacı ruhunu korumaya çalışan kişiler tarafindan bu bostan 100. Yil İşçi Blokları Mahallesi sakinleri tarafindan 2015 yılında kurulmuştur (Şekil 2). Amaç, insanların birbirini daha yakından tanımasını sağlamak, mahalle kültürünü ve komşuluk ilişkilerini geliştirmek olarak tanımlanmıştır. '100. Y1l Mahalle Atölyesi' kapsamında '100. Yıl İnisiyatifi' adı altındaki dernek tarafından çalışmalar yürütülmektedir (100.Yıl Berkin Elvan Bostanı, 2021).

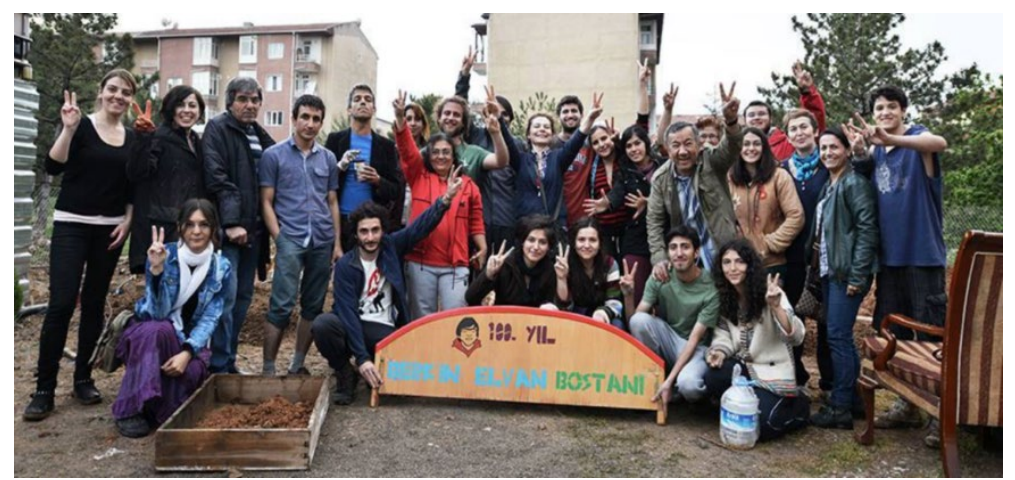

Şekil 2: Yüzüncüyıl Berkin Elvan Bostanı (Kaynak: Ekoharita, 2016)

Kuzguncuk Kent Bostanı

İstanbul'un yeşil alanlarından olan ve 700 yıldır Kuzguncuk Mahallesi içinde korunmuş, ürün vermeye devam eden bu bostan, Kuzguncuklular 
Derneği ve mahalle sakinleri tarafından korunmaktadır. Eski adıyla İlya Bostanı olarak geçen bu alan tarımsal üretimin için kullanıldığı gibi aynı zamanda sosyal bir toplanma alanı görevi de görmektedir (Şekil 3). Kuzguncuklu mimarların girişimiyle bostana ilişkin alternatif proje geliştirilerek mevcut kullanımını koruyarak, çocuk atölyeleri, dinlenme alanları, yürüyüş parkurları gibi hayaller kurulmuş, permakültür tasarımı ile bu alana ilişkin çeşitli alternatifler de geliştirilerek mahalleli ile paylaşılmıştır. Yılın belirli günlerinde bostanda şenlikler ve üretim günleri düzenlenmektedir (Sayan, H. S., 2014).

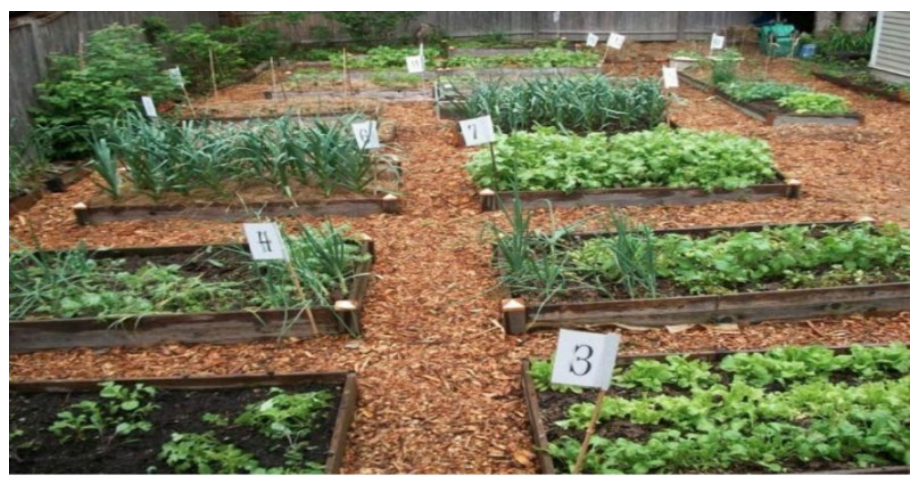

Şekil 3. Kuzguncuk Kent Bostanı (Kaynak: Sayan, H. S., 2014)

\section{Yedikule Bostanları}

İstanbul'da kentsel tarımın önemli temsilcilerinden olan "Yedikule Bostanları", hem tarım mirasına sahip çıkmakta hem de güvenli, sağlıklı, yerel gıda üretimin devamlılığı açısından önemli bir yere sahiptir. Yedikule'deki verimli bostanlar Osmanlı'dan günümüze gelebilmiş ve bugünlerde de Yedikule Koruma Girişimi sayesinde hem üretken hem de sosyal bir mekân olarak korunmaya çalışılmaktadır (Şekil 4). UNESCO Dünya Miras Listesi'nde yer alan İstanbul Kara Surları koruma bandındaki Tarihi Yedikule Bostanları'nı dönüşüm tehdidi altında olsa da başta Yedikule Bostanları Koruma Girişimi olmak üzere STK'lar bostanların korunması için mücadele verirken tarımsal üretimlerini de sürdürmeye çalışmaktadırlar (Sayan, H. S., 2014). 


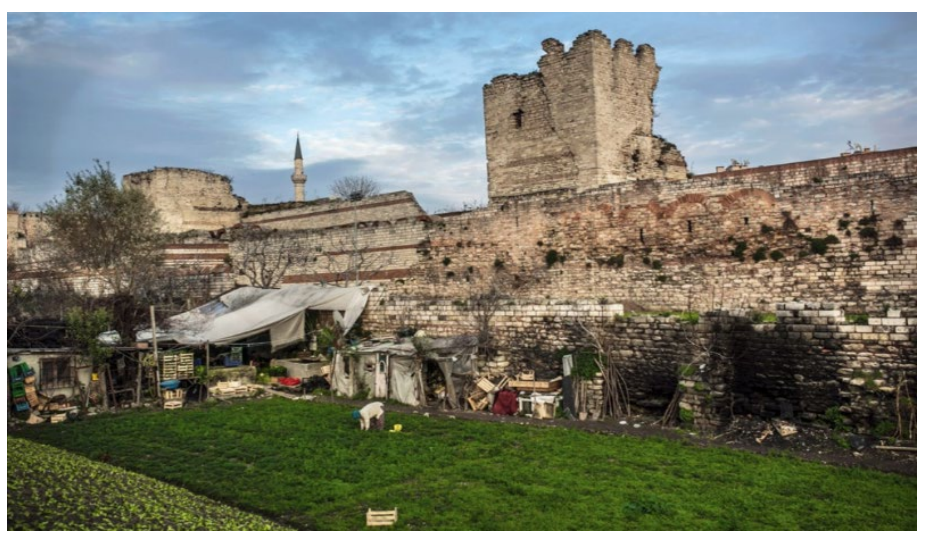

Şekil 4. Yedikule Bostanları (Kaynak: Sezgin, 2015)

Türkiye'deki dernekler ve STK'ların destekleri ile oluşturulan kent bostanlarının yanı sıra dünyada da STK'lar ve toplum gönüllüleri aracılığı ile oluşturulan kentsel tarım örnekleri mevcuttur. Bu dünya örneklerinden bazılarına değinmek çalışmadaki kentsel tarım konusunun oluşumsal bağlamını güçlendirecektir.

\section{Dünyadan örnekler}

Bu bölümde Amerika Birleşik Devletleri başta olmak üzere başarılı kentsel tarım uygulamalarının gerçekleştirildiği görülmektedir. Bu örnekler aşağıda değerlendirilmektedir.

\section{Wolcott Street Farm (Brooklyn, New York, ABD)}

Şehir merkezi ve denizin arasında kalan boş arazilerin dönüştürülmesi ile oluşturulan bu kentsel çiftlik alanının kurulmasında gönüllü bir dernek öncü olmuştur. Yetiştirilen ürünler çiftlik stantlarında satılmakta, geliştirilen bir paylaşım programı aracılığı ile ailelere dağıtılmakta, yerel gıda depolarına bağışlanmakta, ya da çiftlikte çalışan gençler ürünleri evlerine götürebilmektedirler. Yani pek çok kişi bu kentsel çiftlikte yetiştirilen ürünlerden faydalanmaktadır (Şekil 5). Çiftliğin kuruluş amacı boş arazileri canlı kentsel çiftliklere dönüştürmek, sağlıklı, uygun fiyatlı ürünlere erişimi iyileştirmek ve gençleri çiftlikte eğiterek yeni nesil yeşil liderleri yetiştirmektir (Red Hook Farms, 2021). 


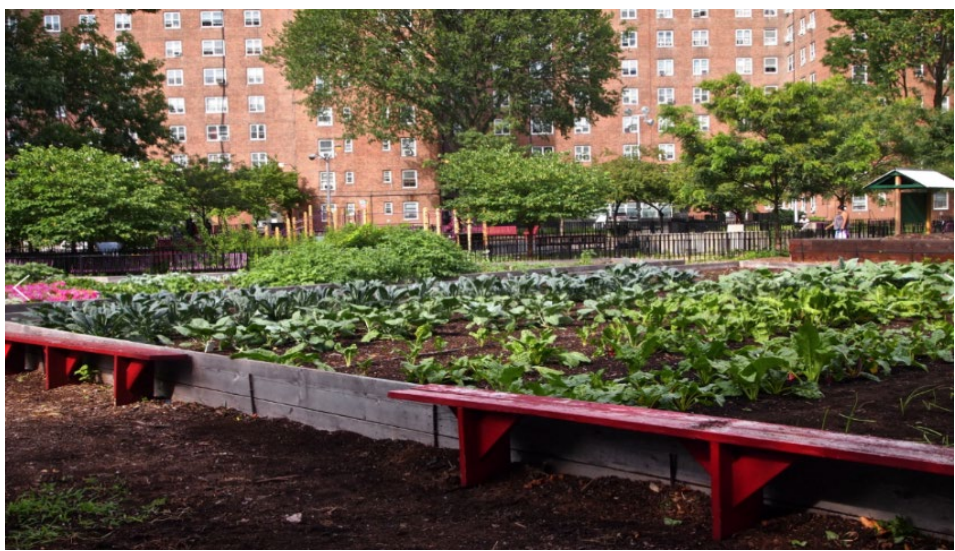

Şekil 5. Wolcott Street Farm - Brooklyn, New York (Kaynak: Red Hook Farms, 2021)

\section{Perth Kent Çiftliği (Avusturalya, Perth)}

Şehir içinde âtıl kalmış, kullanılmayan arazinin dönüştürülerek bir kent çiftliği haline getirilmesi ile oluşturulan bu alanda amaç, her yaştan insana öğrenme deneyimi sunmak, sosyal sermaye ve toplum katılımını teşvik etmek ve bu insanları sürdürülebilir yaşam uygulamalarının önemi ve kolaylığı konusunda eğitmektir (Şekil 6). Alan gönüllü bireyler tarafından oluşturulmuştur. Alanın işletmesinde yaklaşık 60 gönüllü ve işsiz genç çalışmaktadır. Alan çok amaçlı kullanılmakta, çeşitli meyve ve sebze üretimi yapılmakta, kümes hayvanları yetiştirilmekte, atık yönetimi sağlanmakta ve düğün dahil birçok organizasyona ev sahipliği yapmaktadır. Aynı zamanda alanda sanat ve topluluk odası bulunmakta çocuklar ve yetişkinler için atölyeler düzenlenmektedir (Evans, P, N,. (2021).

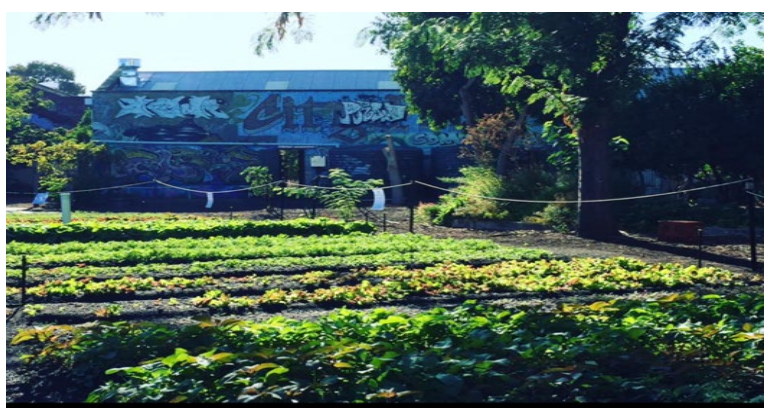

Şekil 6. Perth Kent Çiftliği-Avusturalya, Perth (Kaynak: Evans, P, N,. 2021)

Keep Growing Detroit Çiftliği (ABD, Michigan, Detroit)

Sanayisizleşme ile birlikte nüfusun üçte birinin kenti terk ettiği yerleşimde 1990'lardan bu yana kalan sakinler ve gönüllü kuruluşlar gıda güvensizliği 
ve yoksulluğa karşı kent bahçeleri ve çiftlikleri kurmuşlardır. Bireyler kent bahçeciliği faaliyetlerine katılırken kendilerini besleyebilmenin sağlıklı ve güvenli yollarını öğrenmişlerdir (Şekil 7). Aynı zamanda bu bahçeler farklı sosyal grupları ve kuşakları bir araya getirerek toplumun yeniden yaratılmasına aracı olmuştur (Keep Growing Detroit, 2021).

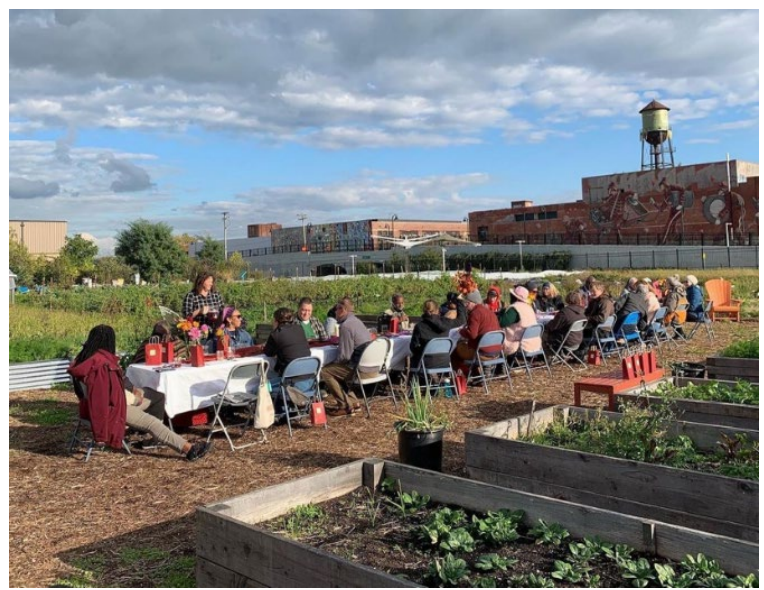

Şekil 7. Keep Growing Detroit Kent Çiftliği-ABD, Michigan, Detroit (Kaynak: Keep Growing Detroit [@keepgrowingdetroit], 2021)

\section{Tartışma ve Sonuç}

Türkiye ve dünya örneklerinde de görüldüğü üzere mahalle ölçeğinde gerçekleştirilen kentsel tarım uygulamalarında STK'ların, vatandaş inisiyatiflerinin, aktivistlerin rolü büyüktür. Oluşumsal çerçeveden gelen bu örnekler değerlendirildiğinde kentsel tarımın amaçları şu şekilde özetlenebilir;

- Güvenli ve sağlıklı, yerel gıda üretiminin devamlılığını sağlamak.

- Organik ve doğal ürün yetiştiriciliği yapmak.

- Boş arazileri üretim için değerlendirmek.

- Bitki türlerinin tanınmasını sağlamak.

- Ürün yetiştiriciliği ile ilgili bilgi paylaşımında bulunmak.

- Çocuklarla ve gençlere tarım ile ilgili temel eğitimleri vermek onları bu konuda yetiştirmek.

- Toprakla bütünleşmeyi sağlamak.

- Uygun fiyatlı ürün sağlamak.

- Dayanışma ruhunu oluşturmak.

- Mahalle kültürünü ve komşuluk ilişkilerini geliştirmek.

- Sosyal bir toplanma alanı yaratmak.

- Farklı kuşakları bir araya getirmek. 
- Şenlikler ve etkinlikler düzenlemek.

- Sosyal sermaye oluşturmak ve toplum katılımını teşvik etmek ve toplum katılımını teşvik etmek.

Bu amaçlardan da anlaşılacağı üzere kentsel tarım ekonomik, çevresel ve toplumsal olarak kentlere hizmet etmektedir.

COVID-19 salgın koşulları sonucunda birçok ülke tarımsal ürüne erişme konusunda problemlerle karşı karşıya kalmıştır. Bu koşullar gıda güvenliği ve tedariği açısından bakıldığında daha yüksek perakende fiyatları, azalan gelirler, giderek daha fazla hane halkının gıda tüketiminin miktarını ve kalitesini kısmak zorunda kalması anlamina gelmektedir (World Bank, 2021). Tarımsal ürünlere erişim konusundaki sıkıntılar ve salgın sürecinin devamındaki belirsizliklerle birlikte, bu ve buna benzer koşullara karşı daha dirençli topluluklar haline gelebilmeye katkı sağlayabilecek önemli oluşumlardan biri kentsel tarımdır. Kent içinde bireysel ya da topluluk olarak örgütlenerek yapılan kentsel tarımın ekonomik faydalarının yanında, daha güvenli gıdaya erişim sağlanarak desteklenen insan sağllğ 1 boyutu ve bunun yanında birlikte üretim ve toprakla ilgilenmenin getireceği serbest zaman etkinliği ile birlikte desteklenen sosyal ve psikolojik fayda boyutu da bulunmaktadır. Salgın sürecinin getirdiği kısıtlamalar karşısında kentsel tarım sağladığı bu ekonomik, sağlık, sosyal ve psikolojik getiriler ile Türkiye'de de önemli bir kentsel üretim şekli olarak belirmektedir.

Kentsel tarım konusunda Türkiye'de bir üst çerçeve eksikliği bulunmaktadır. Bu eksiklik, dünyada STK girişimleriyle öne çıan yerel girişim örneklerinin getirdiği oluşumsal çerçeve nedeniyle, yalnızca gerçekleştirilecek olası yasal düzenlemelerle çözülmesi mümkün değildir. Yapısal çerçeve olarak ele alınan yasal mevzuat, politika ve plan belgeleri tek başına yeterli olmasa da getirdiği fırsatlar ile birlikte önemli bir tamamlayıc olarak öne çkmaktadır. Yerel yönetimlerin kentsel tarım düzenlemelerini de içerecek şekilde, yönetmelik çkarma veimar planı ve projeler hazırlama yetkisi ve bu belgelerin eki olarak tasarım rehberleri hazırlanabilme potansiyeli bu tamamlayıc çerçevenin getirdiği fırsatlardır.

Türkiye'de kentsel tarım konusunda yapısal olarak hala bir netlik bulunmamaktadır. Başka bir değişle mevzuatta kentsel tarım ile ilgili tanım, yöntem ve düzenlemeler konusunda eksiklikler vardır. Bununla beraber kentsel tarımı etkileyebilecek üst çerçeve kuralları içeren kanun ve yönetmelikler bu konu ile ilgili çıarsamalar yapılacak bazı kanun ya da yönetmelik maddeleriyle birlikte kimi potansiyelleri bünyesinde barındırmaktadır. Mevzuattaki bu boşluk STK'ların, vatandaş inisiyatiflerinin geliştirdiği oluşumsal müdahalelerle doldurulduğu pratikte görülmektedir. 
Bu anlamda, STK'ların kentsel tarım girişimlerinde önemi çalışmada vurgulanmıştrr. Kentsel tarım çerçevesi arayışında bu araştırma göstermiştir ki, yapısal ve oluşumsal müdahellerin birlikteliği ve birbirini tamamlayıc nitelikte olması gerekmektedir. Türkiye'de kentsel tarım, mevzuat düzeyinde tanınmall, yapısal çerçeveningetirdiği firsatlar kullanılmalı ve gerekli esneklik sağlanarak STK'ların da bu konuda girişim yapabileceği alanlar sağlanmalıdır. Bunun yanında, STK'ların kentsel tarım konusundaki girişimleri yerel ve merkezi yönetim tarafindan desteklenmelidir. Vatandaşların sorumluluk alarak aktif bir yurttaş olmaların sağlayan STK'lar günümüz demokrasinin önemli bir aktörüdür. Kentsel tarmm konusunda da STK'ların oluşumsal rolü özellikleyerel ölçekte kentsel tarım uygulamaları için oldukça önemlidir.

STK'lar yerelde bireyin toplumsal ve siyasi katlımının anahtar oluşumlarındandır. Kentsel tarım örgütlenmesini destekleyecek ya da girişimde bulunabilecek STK'lar yapısal ve oluşumsal çerçevelerin birlikteliğinde anahtar rol oynayacaklardır. Bu birliktelik ile kurgulanabilecek yeni çerçeve bir yandan da yukarıdan-aşağıya (up-to-bottom) ve aşağıdan yukarıya (bottom-up) yaklaşımların da birlikteliği şeklindeöne çıkmaktadır. Yukarıdan aşağıya yaklaşım, yapısal çerçevenin getireceğiüst kararlar tarafindan temsil edilirken;STK öncülügü̈nde geliştirilecek kentsel tarım uygulama örnekleri de yerel demokrasi ve katılımalığın anahtarı olan STK'lar tarafindan temsil edilen aşağıdan-yukarıya yaklaşımı beraberinde getirmektedir. Diğer bir deyişle, kentsel tarım çerçeve arayışı çalışması sonucunda öne çıkan yapısal ve oluşumsal çerçevelerin birlikteliği aynı zamanda şu anlama gelmektedir; üst çerçevenin belirlediği kurallar yerel çerçevenin STK öncülügündeki katılıma pratikteki girişimleri ile birleşerek daha esnek, karar mekanizmasını yerelde tutan, katlımalık ve politika-yapım mekanizmaları açısından yerele hareket alanı sağlayan ve daha dirençli yapilanmaların yaratlabilmesidir. 


\title{
Extended Abstract
}

\section{Structural and Formative Framework of Urban Agriculture in Turkey}

\author{
Serap Kayasü \\ ORCID: 0000-0001-8477-0632
}

Büşra Durmaz

ORCID: 0000-0003-2792-9592

It is a known fact that $75 \%$ of global and natural resources are consumed in cities. Fertile land, food, clean water and clean air are dramatically scarce and the world is rapidly moving towards a state of famine. Small-scale manufacturing, circularity in the urban built environment and circular economy and urban agriculture are some of the applications for nature-based solutions.

There is no framework that includes a clearly developed definition, method, restrictions and possibilities for the Turkish practices of urban agriculture -as the emphasis of this research-. It is necessary to clarify how urban agriculture will be conceptually positioned, on what legal basis in practice, or by taking into account an external rule or example, new practices can be made.

The context of this research is Structural and Formative Framework of Urban Agriculture in Turkey. For structural framework; legislations, plans, strategy and policy documents on urban agriculture in Turkey are examined. In the analysis of strategy and policy documents, national, urban and district-scale studies were examined, and Ankara province and Çankaya district were taken as examples. For formational framework, Non-Governmental Organizations (NGOs) constitute urban agricultural areas and practices created through organizational structures and citizen initiatives.

There are important deficiencies in the rules, definitions and implementation examples of urban agricultural practices and research in Turkey. Therefore, two complementary stages will be detailed in the process of creating a holistic framework for urban agriculture, as structural and formational framework. 
Structural framework is composed of rules in agricultural production and urbanization legislation that can often be indirectly associated with urban agriculture. As a complement to the structural framework, the analysis of strategy and policy documents and plans reveals important inputs related to urban agriculture, especially at the regional and local scale. In the analysis of strategy documents and plans, Ankara (city scale) and Çankaya (district scale) were analyzed as sample scales. In this context, parts that can be directly or indirectly associated with urban agriculture are specified. In the examination, the definition of urban agriculture in the $9^{\text {th }}$ Development Plan 2007-2013 Special Specialization Commission Reports-Settlement and Urbanization Report and the 2023 Capital Master Plan, the decisions taken regarding AOÇ could be associated with the most prominent and urban agriculture. It can be seen from the examinations that there are notable constraints on urban agriculture in the context of Ankara. On the other hand, there are important areas of intervention by local governments for the purpose of urban agriculture.

In the formational framework, the form and method of the formation gain importance. In other words, while the legislation and binding plan/policy documents that form the rules in the structural framework constitute the lower part of the main framework, the scale and how the urban agriculture practice carried out in the formation framework constitutes the other part of the main framework. In this part of the study, the issue of urban agriculture in Turkey was evaluated in the context of the formational framework of urban agriculture by considering the neighborhood as sample research scale. NGOs, organizational structures and citizen initiatives constitute the formational context of urban agriculture. Çiğdemim Mahalle Garden, Mutlukent Garden, Yüzüncü Yıl Berkin Elvan Garden, Kuzguncuk City Garden and Yedikule City Gardens are given as examples for these formations in Turkey, while Wolcott Street Farm and Keep Growing Detroit Farm in the USA, Perth City Farm in Australia are the international examples. Another remarkable feature of these formations is that, as a neighborhood organization in each of them, the associations are structured through the influence and mediation of NGOs.

NGOs, citizen initiatives and activists have a great role in urban agriculture practices carried out at the neighborhood scale. When these examples from the formational framework are evaluated, the objectives of urban agriculture initiatives are;

- To ensure the continuity of safe and healthy local food production.

- Togrow organic and natural products.

- Utilizing vacant lands for production. 
- To ensure the recognition of plant species.

- To share information about product cultivation.

- To give basic training about agriculture to children and young people.

- To ensure integration with the soil.

- Providing affordable products

- To create a spirit of solidarity.

- To develop neighborhood culture and neighborhood relations.

- Creating social public spaces.

- Bringing different generations together.

- Organizing festivals and events.

- Building social capital and promoting community participation and promoting community participation.

There is a lack of an upper framework for urban agriculture in Turkey. Due to the formational framework brought by the examples of local initiatives that stand out with NGO initiatives in the world, it is not possible to solve this deficiency only with possible legal arrangements to be made. Although the legal legislation, policy and plan documents, which are considered as a structural framework, are not sufficient on their own, they stand out as an important complement with the opportunities they bring. The authority of local governments to issue regulations and prepare zoning plans and projects, including urban agricultural regulations, and the potential to prepare design guides in addition to these documents are opportunities brought by this complementary framework.

There is still no clear structural determination on urban agriculture in Turkey. There are deficiencies in the definition, methods and regulations in the legislation. However, laws and regulations containing upper framework rules that may affect urban agriculture contain some potentials along with some laws or regulations. In practice the gap in the legislation is filled by the formational interventions developed by NGOs and citizens' initiatives. Therefore, importance of NGOs in urban agriculture initiatives was emphasized.

Structural and formational interventions need to be together and complement each other. Urban agriculture in Turkey should be recognized at the legislative level, opportunities of structural framework should be utilized, and areas where NGOs can take action should be provided. The initiatives of NGOs on urban agriculture should be supported by the local and central government. NGOs, enabling citizens to take responsibility and become active citizens, are prominent actor of today's democracy. The formational role of NGOs in urban agriculture is significant particularly at local scale. 


\section{Kaynakça/References}

Ankara Büyükşehir Belediyesi. (2006). Ankara büyükşehir belediyesi-imar ve şehircilik dairesi başkanlı̆̆ 2023 başkent ankara nazım imar planı plan açılama raporu: etüdlerEmüdahale biçimleri. $10 \quad$ Mart 2021 tarihinde https:/www.ankara.bel.tr/files/6715/1323/4013/sosyal-yasam.pdf adresinden erişildi.

Ankara Kalkınma Ajansı. (2020a). Kentsel tarım stratejisi belgesi: çankaya ilçesi uygulama örneği, ankara, Proje ekibi: Prof. Dr. Serap Kayasü - dr.öğr.üy. a. Burak Büyükcivelek - arş. gör. Büşra Durmaz - arş. gör. Selen Karadoğan - öğr. Pelin Akça: $\quad 17 \quad$ Ekim $2021 \quad$ tarihinde http://kutuphane.ankaraka.org.tr/upload/dokumandosya/kentsel-tarimstratejisi_2020_.pdf adresinden erişildi.

Ankara Kalkınma Ajansı. (2020b). Ankara bölgesel yenilik stratejisi. 10 Eylül 2021 tarihinde https://www.ankaraka.org.tr/tr/ankara-bolgesel-yenilik-stratejisi_4700.html adresinden erişildi.

AU Online. (2019). History of urban agriculture. AU Online Aurora University, Illinois. 14 Mart 2021 tarihinde https://online.aurora.edu/history-of-urban-agriculture/ adresinden erişildi.

Birleşmiş Milletler. (2021). Sustainable development report 2021. Cambridge University Press. 13 Nisan 2021 tarihinde https://sdgindex.org/reports/sustainabledevelopment-report-2021/adresinden erişildi.

Çankaya Belediyesi. (2019a). Çankaya sağlkkl kent projeleri 2014-2019. ankara: çankaya belediyesi dış ilişkiler müdürlü̆g̈u sağlkkl kent proje ofisi. 20 Nisan 2021 tarihinde http://www.skb.gov.tr/wp-content/uploads/2019/03/Cankaya-Saglikli-KentProjeleri-2014-2019.pdf adresinden erişildi.

Çankaya Belediyesi. (2019b). Çankaya belediyesi 2020-2024 stratejik planı. ankara: çankaya belediyesi strateji geliştirme müdürlüğü. 20 Nisan 2021 tarihinde http://www.sp.gov.tr/tr/stratejik-

plan/s/1978/Cankaya+Belediyesi+_Ankara_+2020-2024 adresinden erişildi.

Çiğdemim Derneği. (2017). Çiğdemim derneğ̈i. https://www.facebook.com/groups/1420150371379337/ adresinden erişildi.

Çiğdemim Mahalle Bostanı. (2020). Çiğdemim mahalle bostanı tantımı. https://www.cigdemim.org.tr/?p=12937 adresinden erişildi.

Devlet Planlama Teşkilatı. (2007). 2007-2013 Dokuzuncu kalknma plant-özel ihtisas komisyon raporu: yerleşme-şehirleşme. Ankara. 14 Nisan 2021 tarihinde https://www.sbb.gov.tr/ozel-ihtisas-komisyonu-raporlari/ adresinden erişildi.

Ekoharita. (2016). 100. yl berkin elvan bostanı. 21 Ekim 2021 tarihinde https://www.ekoharita.org/project/100-yil-berkin-elvan-bostani/ adresinden erişildi.

Evans, P, N,. (2021). History of perth city farm. 21 Ekim 2021 tarihinde https://perthcityfarm.org.au/gardening/history/adresinden erişildi. 
FAO. (2011). The place of urban and peri-urban agriculture (upa) in national food security programmes. Rome: Integrated Food Security Support Service (TCSF) Policy and Programme Development Support Division Technical Cooperation Department.

Keep Growing Detroit [@keepgrowingdetroit]. (2021, 21 Ekim.). Keepgrowingdetroit. 2 Kasım 2021 tarihinde https://www.instagram.com/p/CVibBIMFgYE/?utm_medium=copy_link adresinden erişildi.

Keep Growing Detroit. (2021). Keep growing detroit. cultivating a food-sovereign detroit. 5 Ekim 2021 tarihinde http://detroitagriculture.net/ adresinden erişildi.

Philips, A. (2013). Designing urban agriculture: a complete guide to the planning, design, construction, maintenance and management of edible landscapes. Wiley.

Red Hook Farms. (2021). Wolcott street farm, red hook farms. 25 Eylül 2021 tarihinde http://www.added-value.org/aboutus adresinden erişildi.

Sayan, H. S. (2014). Kentin gizli bahçeleri: kent bostanları. 25 Eylül 2021 tarihinde https://www.tarim.com.tr/Kentin-Gizli-Bahceleri-Kent-Bostanlari,29044h, adresinden erişildi.

Sezgin. (2015). Yedikule bostanları; mirasın talanı., Atlas Dergisi Şubat 2015. 7 Kasım 2021 tarihinde https://www.atlasdergisi.com/gundem/yedikule-bostanlari-mirasintalani-2.html adresinden erişildi.

Taluğ, C. (2020). Kentsel tarım ve gıda güvenliği. 25 Eylül 2021 tarihinde https://www.youtube.com/watch?v=e2LzT-mWYPM adresinden erişildi.

United Nations. (2015). Brief for gsdr 2015 - urban agriculture. department of economic and $\begin{array}{lllll}\text { social affairs. } & 20 & \text { Eylül } & 2021 & \text { tarihinde }\end{array}$ https://sustainabledevelopment.un.org/index.php?page=view\&type=111\&nr=5 $764 \&$ menu $=35$ adresinden erişildi.

World Bank. (2021). The world bank: understanding poverty. food security and covtd-19. 20 Eylül 2021 tarihinde https://www.worldbank.org/en/topic/agriculture/brief/food-security-andcovid-19 adresinden erişildi.

100.Yıl Berkin Elvan Bostanı (2021). 100. yıl berkin elvan bostanı'nı yeşertiyoruz. Fongogo Kitle Fonlama Platformu. 19 Ekim 2021 tarihinde https://fongogo.com/Project/100-yil-berkin-elvan-bostanini-yesertiyoruz adresinden erişildi. 